Portland State University

PDXScholar

8-7-1995

\title{
School Attendance and Achievement in a Population of Ecuadorian Underage Street Workers
}

Rossana Viteri

Portland State University

Follow this and additional works at: https://pdxscholar.library.pdx.edu/open_access_etds

Part of the Sociology Commons

Let us know how access to this document benefits you.

Recommended Citation

Viteri, Rossana, "School Attendance and Achievement in a Population of Ecuadorian Underage Street Workers" (1995). Dissertations and Theses. Paper 4925.

https://doi.org/10.15760/etd.6801

This Thesis is brought to you for free and open access. It has been accepted for inclusion in Dissertations and Theses by an authorized administrator of PDXScholar. Please contact us if we can make this document more accessible: pdxscholar@pdx.edu. 
THESIS APPROVAL

The abstract and thesis of Rossana Viteri for the Master of Arts in Sociology were presented August 7,1995, and accepted by the thesis committee and the department

COMMITTEE APPROVALS:

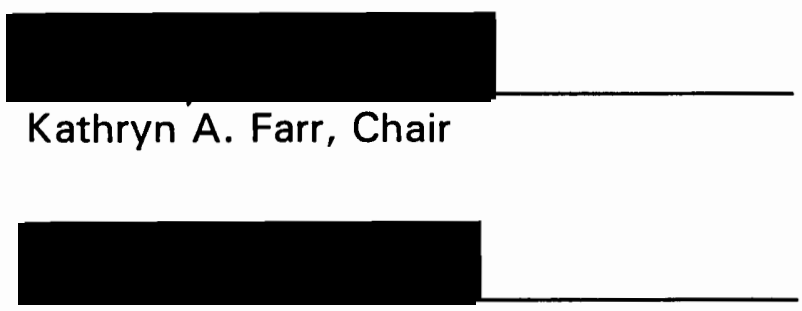

Grant M. Farr

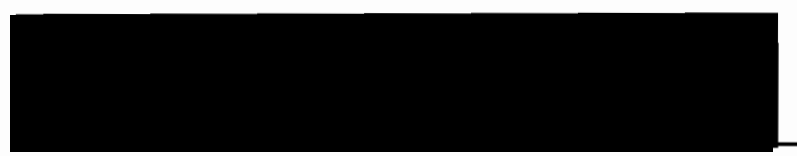

Maria Wilson-Figueroa

DEPARTMENT APPROVAL:

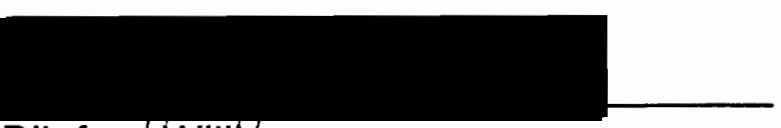

Dilafruz Willáms

Representative of the Office of Graduate Studies

Robert W. Shotola, Chair Department of Sociology

ACCEPTED FOR PORTLAND STATE UNIVERSITY BY THE LIBRARY

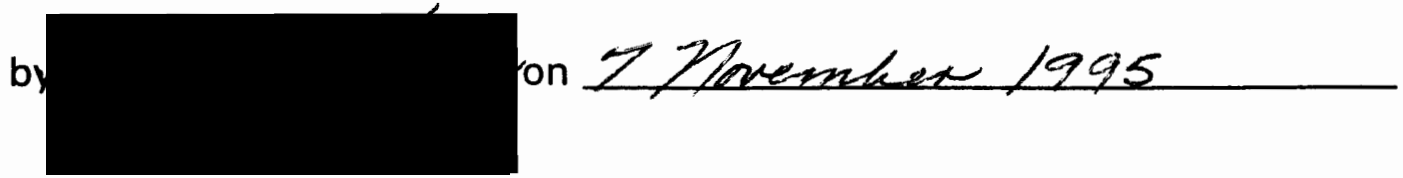




\section{ABSTRACT}

An abstract of the thesis of Rossana Viteri for the Master of Arts in Sociology presented August 7, 1995.

Title: School Attendance and Achievement in a Population of Ecuadorian Underage Street Workers

Underage street work is a social problem that is on the increase in Ecuador. Children, ages 5 to 17 , wander through the streets in an attempt to make some money for their own survival or to help their families survive. The literature on underage street workers (USWs) reports that the working activities of these children impact their health and education.

This study examined school attendance and achievement of USWs who are affiliated with an underage workers program in Ecuador. Using a quantitative methodology, the study looked at variations by location and age, with a special focus on gender issues, as there is some evidence that these variables affect the school behavior of the USWs.

Among the population of USWs, there is a significant group of girls who work on the streets. According to the literature, female underage workers are in a disadvantaged position compared to boys because of the 
generally inferior position held by women in Latin America and, specifically, because these girls are overloaded with both productive and domestic activities. This overload interferes with their education and the possibility of their upward mobility. Education, according to several studies done in Latin America, opens up a wider range of opportunities and is an important instrument in women's upward mobility. However, there is controversy over the benefits of education for poor women.

The data for this study were drawn from the Program's data base; three locations were chosen, and the sample subjects were followed up for 18 months, during which time they were evaluated every 6 months.

The hypothesized male advantage in school attendance and achievement was not supported; at the elementary level, more USWs girls than boys were attending school, although at the secondary level there were actually no differences between genders. School achievement was found to be similar for both genders. However, significant differences in school attendance and achievement were found by age and location; younger USWs were more likely to attend school and perform satisfactorily than older ones. Regarding location, the largest city, Cuenca showed higher rates of school attendance and achievement than the other sample sites. 
SCHOOL ATTENDANCE AND ACHIEVEMENT IN A POPULATION OF ECUADORIAN UNDERAGE STREET WORKERS

by

ROSSANA VITERI

A thesis submitted in partial fulfillment of the requirements for the degree of

MASTER OF ARTS

in SOCIOLOGY

Portland State University

1995 
TABLE OF CONTENTS

PAGE

LIST OF TABLES $\ldots \ldots \ldots \ldots \ldots \ldots \ldots \ldots \ldots \ldots$ iv

CHAPTER

I INTRODUCTION $\ldots \ldots \ldots \ldots \ldots \ldots \ldots \ldots$.

II REVIEW OF THE LITERATURE AND CONCEPTUAL

FRAMEWORK $\ldots \ldots \ldots \ldots \ldots \ldots \ldots 8$

Underage work $\ldots \ldots \ldots \ldots \ldots \ldots \ldots 8$

Defining the Population of

Underage Workers

Working Activities of USWs

Income

Intensity

Risks and Consequences of

Underage Work

Programa Trabajadores Prematuros . . . . . . 22

Women in Latin America . . . . . . . . . . 27

Women in Ecuador

Education and Gender ............. 34

Education in Ecuador Today

Education and Women in Latin

America

Education: Advantages and

Disadvantages for Women

Some Notes on Educational Change 
III METHODOLOGY ................44

IV THE FINDINGS $\ldots \ldots \ldots \ldots \ldots \ldots \ldots$

Characteristics of the Sample . . . . . . . . . 54

Location

Gender

Age

School Attendance . . . . . . . . . . . . 61

By Age

By Location

By Gender

Summary

School Achievement . . . . . . . . . . . . 95

By Age

By Location

By Gender

Summary

$\checkmark \quad$ DISCUSSION OF THE FINDINGS $\ldots \ldots \ldots \ldots \ldots 114$

School Attendance . . . . . . . . . . . . . . 114

By Age

By Location

By Gender

Summary

School Achievement . . . . . . . . . . 128

By Age

By Location 


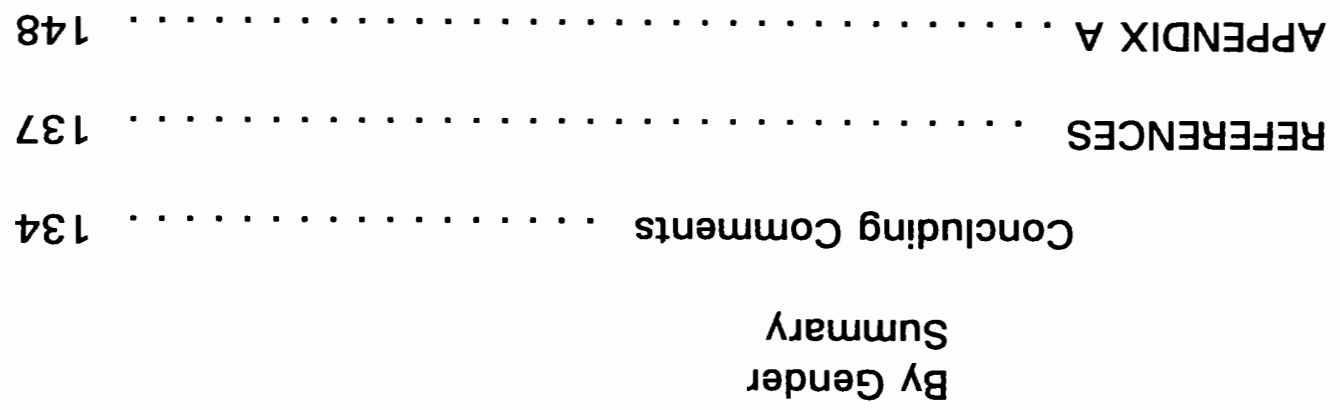

Tุ? 


\section{LIST OF TABLES}

TABLES

PAGE

1

2

3

4

5

6

7

8

9

10

11

12
Sample Distribution by Gender and Location . . . . . . . . . . . 56

Age of the Sample by Gender . . . . . . . . . 60

Age of the Sample by Location . . . . . . . 60

School Attendance: Base Line and

Follow-up . . . . . . . . . . . 62

Elementary School: Base Line and

Follow-up . . . . . . . . . . . 64

High School Attendance: Base Line and Follow-up . . . . . . . . . . 64

School Attendance by Age . . . . . . . . 6 68

School Attendance of USWs 12 and

Older .................. 70

School Attendance by Location . . . . . . . . . 75

School Attendance by Gender . . . . . . . . . . . 79

Female USWs School Attendance by

Age ................ 81

School Attendance of Female USWs

Older than $12 \ldots \ldots \ldots \ldots$........ 82 
Male USWs School Attendance by Age .................. . 85

School Attendance of Male USWs Older than $12 \ldots \ldots \ldots \ldots$. . . . . 87

School Attendance of Male USWs by Location . . . . . . . . . . . . 89 and Evaluation Periods . . . . . . . 97

School Achievement of USWs by Age ................. . 99

School Achievement of USWs Older than 12

School Achievement of USWs in

Otavalo by Time Period . . . . . . . . . . . 102

School Achievement of USWs in Ambato by Time Period . . . . . . . . . . 103

22 School Achievement of USWs in Cuenca by Time Period ............ . 104

$23 \quad$ Female USWs School Achievement ................ 106

$24 \quad$ Male USWs School Achievement . . . . . . . 107

$25 \quad$ Female USWs School Achievement by Age ................... 108 
TABLES

PAGE

26 School Achievement of Female USWs by Location . . . . . . . . . . . 109

27

Male USWs School Achievement by Age . . . . . . . . . . . . 110

28

School Achievement of Male

USWs by Location . . . . . . . . . . . . 111 


\section{CHAPTER I}

\section{INTRODUCTION}

Due to the distressing economic situation of the region, Latin American cities have witnessed the increase of underage street workers (USWs) during the last two decades (UNICEF/OIT, 1994; Wright, Kaminsky and Wittig, 1993; Lusk, 1989; Yopo, 1989; Myers, 1988). These children, ages 5 to 17 , wander through the main streets, plazas and markets of the cities attempting to make some money, which is used regularly to contribute to their family's income (UNICEF/OIT, 1994; Wright et al., 1993; Lusk, 1989; Boyden, 1988; Tacon, 1988). The productive activities of USWs typically develop in the informal sector of the economy. Common occupations of the children are: selling items such as candy, lottery tickets, newspapers, flowers, fruits and vegetables, and prepared food; they also shine shoes, wash and watch cars, sing and the like (Wright et al., 1993; Lusk, 1989; Tacon, 1988). Ecuador is not an exception to this phenomenon, and child work has become an acute problem for the country: There are approximately $500,00015 \%$ of the Ecuadorian population) children from 8 to 17 years of age who work, plus a sizeable group of children under 8 years of age who work and about 
whom there are no census data available (UNICEF/DYA, 1992; INEC, 1990). A considerable portion of the underage worker population are girls ${ }^{1}$, however, little attention has been paid to them, as the bulk of the research and the care-providing programs address the situation of the male USWs (Yopo, 1989). Girls who work to survive and/or help their families survive are in a particularly disadvantaged position (Grupo Esquel Argentina, 1989; UNICEF, 1989; Boyden, 1988; Tacon, 1988; Piloti, 1985) because they must accomplish both productive and domestic activities that interfere with their education, and thus with the possibility of upward mobility (Garcia and Hernandez, 1992; Elhers, 1990; Cuvi, Naranjo and Herrera, 1989; Yopo, 1989; Bordia, 1988; Dodge, 1988; Mancilla, 1988; Bernal, 1985).

This study examined the educational behavior (attendance and achievement) of boys and girls who work on the streets and are also affiliated with an underage workers program in Ecuador. It looked at associations between gender and school variables, and how they reflect on or inform about the country's traditional values regarding women and women's roles. It also looked at variations in the educational behavior of USWs by age and across different locations in the country. In sum, the

${ }^{1} 35.1 \%$ of the economically active population age 8 to 19 are girls (INEC, 1990), in addition are girls who do domestic tasks at home and whose work is not taken into account as such (Garcia and Hernandez, 1992; Presidencia, 1992a). 
questions this study addressed were: What is the rate of school attendance and level of achievement of USWs, and, what are the differences in school achievement and attendance by gender, age and location.

There is some evidence that the work overload of USWs results in high levels of school dropout and poor achievement (UNICEF/OIT, 1994). Several authors argue that the intensity of the working activities of USWs (Garcia and Hernandez, 1992; Presidencia, 1992a), plus the dangerous settings in which they are performed (Gunn and Ostos, 1992; INNFA, 1991b; Andrade, 1986) affect USWs' natural developmental process (Lusk, 1989; Boyden, 1988; Myers, 1988; Penna, 1988), particularly their health conditions and educational levels (OIT/UNICEF, 1994; Wright et al., 1993; Presidencia, 1992e; Lusk, 1989; Bequele, 1988; Bernal and Ayala, 1985).

The severity of the problem of child work has led both governmental and non-governmental organizations in the country to develop different care providing programs. Frequently, one of the goals of these programs is to raise the educational levels of the children based on the idea that education has a positive impact on their living conditions (ICCB, 1989; Lusk, 1989; Beneria and Roldan, 1987; Wagner, 1983). One such program is Programa Trabajadores Prematuros of Ecuador, a 
national program that provides an alternative, non-institutional mode of integrated, participatory care designed to improve the children's living conditions, diminish the levels of risk in which they live, and facilitate their development in society ${ }^{2}$. The Program implements different activities and services for USWs in the areas of health, education, recreation and job training (INNFA, 1991a), with a special focus on gender issues, based upon the idea that female USWs are in a particularly disadvantaged position (INNFA, 1991a).

Women in Latin America generally hold an inferior position in society due to cultural and religious beliefs, plus the survival of feudal attitudes, that keep them in a subordinate condition (Lindsey, 1990; Acosta, 1989; Perez, 1989). In spite of this, the situation of women in the region has undergone changes during the last two decades, particularly in the educational area (Hollsteiner and Tacon, 1989; Perez 1987). Access to education by women has increased notably (Stromquist, 1992); however, poor women still have the lowest levels of education in the region (Acosta, 1989; Yopo, 1989; Childhope, 1988; Charlton, 1984). Poor women are the most disadvantaged of all; in addition to lower educational levels, they have far fewer employment

\footnotetext{
${ }^{2}$ As of 1993 the program provided care for 12,500 USWs in 18 cities (Programa Trabajadores Prematuros, 1994b, p.1).
} 
opportunities than either poor men or middle class women (Cantazarite, 1992; Elson, 1991; CEISE, 1988). Despite the fact that women in Ecuador have increased their educational levels and their participation in the labor force land now make a considerable contribution to the family's income [Garcia and Hernandez, 1992; Moser, 1989; Perez, 1987]), the illiteracy rate for women is still considerably higher than the national rate (INEC, 1991).

Studies suggest that formal schooling is necessary for attaining better jobs (Stromquist, 1989) and is an important instrument in women's upward mobility (Fink and Arnove, 1989; Population Reference Bureau, 1986). However, there is some controversy over whether education benefits poor women or not. Several authors regard formal education as a reproducer of existing gender relations through its socialization of women into traditional roles (Braslasvsky, 1992; Stromquist, 1989; Yopo, 1989). Additionally, some data show that formal schooling does not help women in the informal market at all (where most women work) (Fink and Arnove, 1989). All in all, education is not an overall solution to the problems of women (Bourque and Warren, 1987), but it certainly can bring about positive changes for them, particularly long term ones (Beneria and Roldan, 1987). Engle (1983) found a slight association between education and work status, while for Catanzarite (1992), 
education appears to be relevant for stable female participation in the labor force. For Latin American educator, Paulo Freire ${ }^{3}(1985 ; 1973)$, despite his criticism of formal schooling, education is an instrument that fosters social change and liberates the oppressed, women included.

There is some evidence that age and location affect USWs' school attendance and achievement (Novillo, 1994; Presidencia, 1992a; Cuvi et al., 1989; Garcia and Hernandez, 1992). Therefore this study also looked at variations by age and location. The sample sites vary by size of the population, urban/ rural distribution of the population, main economic activities and illiteracy rates (INEC, 1991a,b,c).

The school attendance rate and achievement level of USWs 5 to 17 years old affiliated with the Programa Trabajadores Prematuros in three different locations was examined using quantitative methodology. The data were drawn from the USWs' records in the Information System of the Program. The educational behavior of the USWs was followed for 18 months, during which time they were evaluated every 6 months. In order to look at variations by gender, location and age in school attendance and achievement of the sample, frequency and cross tabulations were analyzed. Changes in the educational behavior of the sample during the

\footnotetext{
${ }^{3}$ Freire is a Latin American Philosopher of Education who developed a pedagogy for the oppressed based on his experiences with people for popular sectors (USWs included), in Brazil and Chile.
} 


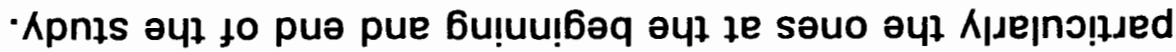

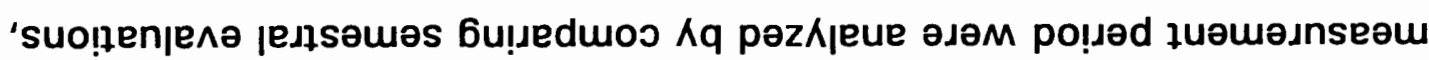




\section{CHAPTER II}

\section{REVIEW OF LITERATURE AND CONCEPTUAL FRAMEWORK}

\section{UNDERAGE WORK}

Definitions and perspectives on child labor have varied considerably during the last hundred and fifty years (Fernandez-Kelly, 1983). Authors argue about what should be considered underage work and what not; some believe that work involves wages while others think that unpaid labor should also be considered as work (Moore, 1983). Another controversy involves the issue of whether work is harmful or not for children; some see it as a non-harmful informal type of education, or as part of the basic socialization process (Piloti, 1985). Others argue that in most cases it is harmful to children's development, even if it is part of socialization (Myers, 1988; Tacon, 1988). Still a third position argues that participation in labor has variable effects on children: "It is not work as such that is damaging to the child, but more the conditions under which most children work" (Boyden, 1988, p.44).

It becomes harmful when it is repetitive, mechanical, physically arduous, and it is undertaken as an obligation. Labor of this kind is often injurious to a child's development, and in extreme circumstances can be exploitative and enslaving (Bordia, 1988, 
p.128).

From a structural point of view underage work is typically a result of inequalities in the distribution of income, that is to say, macro deficiencies in the system that keep a portion of the population in a situation of extreme poverty (UNICEF, 1990; Lusk, 1989; Mancilla, 1988). Underage work, poverty and underdevelopment are seen as related problems (Moore, 1983). In Latin America, a capitalistic model which depends on first world countries' credits, technologies and markets, maintains a considerable segment of the adult population in an impoverished situation with low salaries, unemployment and underemployment, lack of housing, and insufficient educational and health services (Nicolo, 1988). In such situations many parents are unable to meet the basic necessities of their children (UNICEF,1990; Mancilla, 1988), and all able family members are forced to work (Wright et al., 1993, Bernal and Ayala, 1985; Piloti, 1985). Thus, the phenomenon of underage work appears in the context of a severe and ongoing economic crisis as one of the strategies poor families use to ensure their survival (UNICEF, 1990; Fernandez-Kelly, 1983). Mancilla (1988) in her study on Peruvian underage workers argues that the early participation of children in the labor force in low and unstable jobs with few possibilities of upward mobility is a response to the distressed economic situation of 
their families. Nangia (1988) in her study on Indian underage workers reports that "[p]arents want their children to fend for themselves as early as possible. It is even better if they become a source of income to the family" (Nangia, 1988, p.52).

In Ecuador, several studies claim that children basically work because their parents do not have enough resources to fulfill their fundamental needs (Garcia and Hernandez, 1992; UNICEF/DYA, 1992; Marquez, 1990; CEDEJOTA/UNICEF, 1989), and that the use of the labor force of children is a strategy used by families to cope with their situation of extreme poverty (Garcia and Hernandez, 1992). Nevertheless, the analysis of underage work can not be limited to the issue of poverty ${ }^{4}$. Other social phenomena related to it, such as migration, accelerated urban growth, the weakening of family ties, changes in socialization processes, low educational levels of parents and inadequate school systems, need to be taken into account (UNICEF/OIT, 1994; Garcia and Hernandez, 1992; UNICEF/DYA, 1992). In Ecuador, the entrance of children into the labor market is related to ancient forms of family and economic organization, which require extensive use of each family member's labor force (UNICEF, 1990; Andrade, 1986). Child work

${ }^{4}$ Gunn and Ostos (1992) who studied scavenger children in the Philippines, also consider that there are other intervening factors that should be taken into account when analyzing underage work. 
is traditionally the norm in the Andean region of South America, with roots in rural society (Garcia and Hernandez, 1992; Espin, 1987; Piloti, 1985). In this context, work is not seen as harmful, but considered beneficial (Boyden, 1988) ${ }^{5}$ because through working activities children not only contribute to the family's needs but get trained in a job and learn the norms for adult life (Piloti, 1985).

UNICEF (1990), in its analysis of urban underage work, argues that child work is commonplace in some native rural economies. These are characterized by intensive use of the labor force of family members, division of work by gender and age, use of traditional technologies, low capital investment, subsistence production, and family income a product of the contribution of all family members (UNICEF, 1990).

A study by Amoroso and Maldonado (1989) on female USWs who sell flowers in the streets in Quito, argues that for the Indian community to which they belong, the concept of childhood implies an active participation in everyday tasks (both productive or reproductive) from early ages, which basically prepare children for adult roles. Such an approach to childhood contrasts with Western ideas about childhood as a time characterized by the absence of productive responsibilities (UNICEF,

\footnotetext{
${ }^{5}$ In India, work is also part of socialization process and as such not seen as harmful (Bordia, 1988).
} 
1990). It sheds light on the cultural context in which underage work occurs. Within this context, whether underage work as a socialization practice is harmful or not for children depends in great part on the conditions under which it is performed, as Boyden (1988) points out. Underage street work in Ecuador, then, can be seen as a problem related to poverty that emerges in environments where it is seen as a normative social practice (UNICEF, 1990), as long as working conditions are acceptable.

For UNICEF and OIT (1994), and Garcia and Hernandez (1992), there is still another element that should be taken into account when analyzing underage work in Ecuador. They argue that there is a close relationship between poverty, underage work and education. From their perspective, there is evidence that the inadequacy of the educational system to meet the needs of the population encourages underage work (UNICEF/OIT, 1994; UNICEF/DYA, 1992) because public schools fail to retain children, particularly rural and poor children (Garcia and Hernandez, 1992). Children may work in order to be able to go to school, but work interferes with school, and many end up dropping out of school after having tried to work and attend school at the same time (Garcia and Hernandez, 1992). In environments where underage work is perceived as natural, UNICEF and OIT (1994) continue, attending school becomes a 
marginal activity in terms of time, and an obstacle to success in work. In such a scenario, it is pointed out, school failure reinforces child involvement in the labor market. Another factor that reinforces the dropout tendency of underage workers and thus encourages their participation in the labor force, according to UNICEF/DYA (1992), is the teachers' lack of awareness of their students' situation, their authoritative attitude, and the lack of adequate teaching methods and aids for this population. Continued failure and level repetition becomes traumatic both for parents and children who are left with no other options but to work (UNICEF/OIT, 1994; Garcia and Hernandez, 1992).

Lower educational levels of parents are also reported to be related to the entrance of children into the labor market; a higher number of years of schooling of the parents is positively associated with a lower number of underage workers in families (Garcia and Hernandez, 1992). From the perspective of the relatively uneducated parents, their children's lack of skills is the principal cause of school drop out; therefore it is better for them to work, and sometimes the children themselves agree with this position (UNICEF/OIT, 1994; Garcia and Hernandez, 1992). In spite of this, education has been highly valued as a mechanism of upward mobility; parents typically encourage their children to at least finish primary school, and ideally get a high school certificate (Garcia and 
Hernandez, 1992). However, UNICEF and OIT (1994) report that a certain disenchantment with education as a pathway to upward mobility is taking place, because education has not solved the problems of poor families.

\section{Defining the Population of Underage Workers}

Millions of children work in Latin America despite regulations limiting underage work ${ }^{6}$. Most working activities are not highly visible because they are performed in the fields, at home and in domestic service (UNICEF, 1990). However, an increasing number of children can be observed working or living in the streets. The "street children", as they are usually called, are defined as:

... any girl or boy...for whom the street in the widest sense of the word, including unoccupied dwellings, wasteland etc.) has become his or her abode and/or source of livehood; and who is inadequately protected, supervised, or directed by responsible adults (Lusk, 1989, p.57,58).

Proyecto Alternativos in Guatemala and Programa Trabajadores

Prematuros in Ecuador make a further analytical distinction between children in the streets (called USWs in the present study) and children of the streets. The former are those who perform different working activities

In many countries in Latin America (including Ecuador) children under 12 are forbidden to work. There are special protective regulations for working 12 to 14 year olds, such as the number of working hours, types of jobs, and compulsory education (Registro Civil, 1992, Tacon, 1988). 
and usually live with their family or relatives. The latter have lost contact with their families and consider the streets to be their home (Wright, et al., 1993; INNFA, 1992a).

USWs are children usually between 5 and 18 "... who may or may not go to school but, instead, spend the majority of their day helping their families earn a subsistence income" (Wright et al., 1993, p. 84, 85).

Wright et al. (1993) and Garcia and Hernandez (1992) argue that the social problems of USWs are related to their extreme poverty, while those of the children of the streets "result from being essentially familyless" (Wright et al., 1993, p.85).

Fairly conservative estimates of street children in Latin America establish the number between 25 to 40 million $^{7}$, a minority of whom are children of the streets (Wright et al., 1993; Lusk, 1989; Hollsteiner and Tacon, 1983). Estimates of underage workers in Ecuador vary. Underage workers 8 to 19 years old are said to represent approximately $11 \%$ of the economically active population (Garcia and Hernandez, 1992;

UNICEF/DYA, 1992), and come from marginal urban families or first generation migrants (UNICEF, 1990). According to census data there are 507,805 underage workers aged 8 to 19 in Ecuador (INEC, 1990); $41.2 \%$

\footnotetext{
'Usually the census grossly underestimates the incidence of child labor (Boyden, 1988; Oloko, 1988).
} 
are urban dwellers and $58.8 \%$ are rural dwellers; $27.4 \%$ are female and $72.6 \%$ are male. Garcia and Hernandez (1992) report that $77 \%$ of USWs are boys and that the majority of boys are younger than 15 , while most of the female USWs $(80 \%)$ are 15 to 17 years old. Another report (UNICEF/DYA, 1992) suggests that the percentage of urban female underage workers is slightly higher $(35 \%)$ than the overall average. Unfortunately, census data do not provide information about underage workers younger than 8 , nor do they include specific numbers of urban underage workers who work indoors as opposed to in the streets. An estimate by UNICEF/DYA (1990) is that $10.2 \%$ of underage workers aged 12 to 14 work in the streets, but there is no available information about other age categories.

According to the data available, then, most underage workers live with their families, more are rural than urban, and more are male than female. However, regarding gender, it can be speculated that the number of underage worker girls is underestimated because most of the work they do (domestic service, domestic family chores) is not as visible as working in the streets (UNICEF, 1990).

All in all, UNICEF (1990) states in its study on Ecuadorian underage work, that the USW population is growing considerably. Factors that increase the chance of becoming a USW among poor families are being 
the oldest or youngest child and, also, growing up in a large family (Boyden, 1988). Finally, Garcia and Hernandez (1992) report that in family units where women are heads of household, the children's entrance to the labor market occurs at earlier ages.

\section{Working Activities of USWs}

Most of USWs' economic activities are situated in the informal economy of the open-air markets and streets (Wright et al., 1993). In developing countries, says Tacon (1988), underage work is whatever can be done to merely survive each day, and any work is worthwhile because, otherwise, USWs could easily be abandoned by their families. The range of occupations open to USWs depend upon certain conditions such as age, gender and place of work (Boyden, 1988). Additionally, the working activities of the underage workers are often related to their parents' occupation (UNICEF, 1990). The working activities of the female USWs and USWs under 8 years old are closely supervised, while boys over age 12 have more freedom (Boyden, 1988). The most common activities of USWs are selling candy, food, vegetables, fruits, newspapers and the like, shoe-shining, washing and watching automobiles, carrying things, prostituting, lifting wallets, begging and the like (Lusk, 1989; Tacon, 1988). 
Income

The income earned by USWs is usually contributed to the family's income. Marquez (1990) in his study on underage workers who go to school in an Ecuadorian town found that $74 \%$ of the underage workers who go to school worked to contribute to their family's income. Most of the time, the income made by the USW is small, but it varies depending upon the type of activity, location, and age and gender of the worker (Garcia and Hernandez, 1992). However, several studies report, whatever the amount of money, it is typically extremely important for their family's survival (Wright et al., 1993; Boyden, 1988; Mancilla, 1988; Oloko, 1988). In Ecuador, Guerra and Lorant (1991) found that USWs contribute $19 \%$ of the family's income ${ }^{8}$. Some income differences by type of activity reported by Garcia and Hernandez (1992) in Ecuador, are the following: shining shoes is more profitable than selling candy, newspapers, lottery tickets or food. In Guayaquil a USW who shines shoes gets $30 \%$ more than a USW candy hawker, and twice that of a USW newspaper hawker. A study by Balarezo (1988) in Cuenca shows that the monthly income of a USW who shines shoes is $20 \%$ higher than that of a USW who sells candy or food and $40 \%$ higher than that of a

\footnotetext{
${ }^{8}$ Mancilla (1988) in Peru reports a contribution of $13 \%$ to the family's income.
} 
lottery or newspaper hawker.

Intensity

The working conditions of USWs are far from acceptable: long hours of work; no wages or wages below the minimum; no weekly or annual holidays; missing facilities, such as water, space or rest rooms; lack of mobility in most occupations; health hazards; and lack of health centers (MRHT et al. 1994; Garcia and Hernandez, 1992; Nangia, 1988). According to several studies, $50 \%$ to $70 \%$ of USWs work more than 30 hours per week (UNICEF/OIT, 1994; MRHT et al. 1994; Guerra and Lorant, 1991) ${ }^{9}$. Additionally, USWs help at home with domestic chores and do school work if they attend school.

Risks and Consequences of Underage Work

Work is one of the most significant parts of USWs' childhood experience, states Myers (1988). It shapes, this author continues, the personality, skills, opportunities and constraints of USWs. For Tacon (1988), the extremely marginal situation in which USWs live forces them to develop present time attitudes and survival values. Play and

\footnotetext{
${ }^{9}$ Dodge $(1988)$ in her study on street children in Khartoum reports 6 to 14 hours per
} day. 
education for this population, he continues, become luxuries.

Furthermore, Penna (1988) claims that their physical, emotional, intellectual and social development are seriously compromised: "In a sense, every occupation is hazardous, for it not only retards the child's growth and development, but also completes the process of condemning the child worker to a bleak and bereft future" (Nangia, 1988, p.59).

To reside or work on the streets as a minor is to be exposed with little or no protection to the harshest elements of the physical, social, and economic environments. Life on the streets can be characterized by hunger, violence, marginal employment and exploitation. It also consists of a nearly complete absence of privacy, supervision, education, nurturance and security (Lusk, 1989, p.58).

Wright (1993) describes some of the risks to which USWs in Honduras are exposed in the streets while carrying out their daily activities:

Nutritional status and personal hygiene are generally poor; thus, many are debilitated and susceptible to infection. Life in the streets is an obvious risk factor for injuries and disorders due to exposure. Crowded and unsanitary living conditions present optimal vectors for the transmission of infectious and communicable disease. Air and noise pollution are extreme. Extreme poverty prevents customary treatment with over-the counter palliatives such as aspirin, dermatological preparations, or cough syrup. All in all, there is scarcely any aspect of the street existence that does not imperil the physical health of the children" (Wright, 1993, p.89).

Other studies on USWs in Ecuador (MRHT et al. 1994; Garcia and 
Hernandez, 1992; INEM, 1988; Andrade, 1986) and in the Philippines (Gunn and Ostos, 1992), point out similar problems.

Furthermore, Garcia and Hernandez (1992) report that levels of risk for USWs are affected by different variables like: age lespecially combined with gender), work schedules, place of work, and type of work activity. Such is the case of the young girls who work at night selling flowers in the streets or young scavenging children.

Regarding the impact of underage work on the educational levels of USWs, the literature states that frequently the conditions in which these children work negatively affect their school attendance and achievement (UNICEF/OIT, 1994; Wright et al., 1993; Garcia and Hernandez, 1992; Boyden, 1988; Mancilla, 1988).

Studies done by Cuvi et al. (1989) and Garcia and Hernandez (1992) show that underage workers in Ecuador have fewer years of schooling than they should when their age is taken into account, and that school enrollment tends to decrease as age increases. There are no studies that compare the school achievement of USWs and non working children, but research of USWs repeatedly shows their poor school achievement (Presidencia, 1992; UNICEF/DYA, 1992; Marquez, 1990; CEDEJOTA/UNICEF, 1989)。 


\section{PROGRAMA TRABAJADORES PREMATUROS}

When addressing the problem of USWs, there is agreement that it is a social problem requiring intervention, however there are different perspectives regarding types of intervention. Lusk (1988) argues that the way in which a social problem is defined determines the kind of intervention used to deal with it. An understanding of the street children phenomenon as individual pathologies or deficits stresses social control strategies, while an approach to it as macro-deficiencies of the system emphasizes social change strategies. On the basis of these two perspectives, the author continues, programs for street children can be classified as: correctional, rehabilitative, outreach and preventive. The first two emphasize social control, whereas the last two stress social change. Myers (1988) classifies interventions for this population in a somewhat similar way: interventions which focus on structural changes (similar to social change strategies), compensatory services (similar to social control strategies) or a mixture of both. Regarding interventions focused on social change, MRHT et al. (1994) argue that policy to address underage work in Ecuador should include efforts to eliminate work of children under the age of 12 , to protect those who work, and to prevent the need for underage work. Arenas that should to be taken into 
account when designing a policy for this population, according to several studies, are legislation, education, employment, job training, incomegeneration projects, and service provision (Presidencia, 1992;

UNICEF/DYA, 1992). Finally, community based approaches have been found adequate in handling the problem of underage work (Lusk 1988; Nicolo, 1988; Hollsteiner and Tacon, 1983).

Programa Trabajadores Prematuros can be defined as an outreach program that protects USWs by providing various services for them while implementing strategies to impact the problem of underage street work in the mid and long run. Outreach strategies, as defined by Lusk (1988), draw from the Catholic concept of "base communities", and are "...based on the assumption of macro deficiencies in society and on individual empowerment as the best avenue toward the mediation of social problems" (Lusk, 1988,p.71-72).

Programa Trabajadores Prematuros ${ }^{10}$ is a national program designed and administered by the Instituto Nacional del Nino y la Familia (INNFA) ${ }^{11}$ for USWs. INNFA started actions to study and protect USWs in 1983 and, by 1989 , formulated a proposal to address the problem of USWs,

\footnotetext{
${ }^{10}$ The information about the Program was drawn from INNFA, 1991 a.
}

${ }^{11}$ INNFA is an non-governmental organization that deals with the impoverished situation of children and their families, providing services and programs to better the living conditions of Ecuadorian children (INNFA, 1992). 
drawing on the experience gained over that six year period. Programa Trabajadores Prematuros provides an alternative, non-institutional mode of integrated and participatory care for USWs, designed to analyze the problem of underage work in the context of the home unit, the neighborhood and/or native community, and the work environment; to implement strategies to strengthen family and community ties in order to avoid uprooting the USWS, and to facilitate their active involvement in society.

The Program reaches USWs in the streets without removing them from their work, family and community environment; it integrates their families into the Program's activities; and mobilizes the community to optimize the use of resources, expand coverage and improve services. Programa Trabajadores Prematuros provides care to boys and girls from 5 through 17 years of age who work on the streets of the cities Ecuador. Its actual coverage is of 12,430 boys and girls in 18 cities of the country (PTP, 1994a). The Program's goal is to improve the children's living conditions, reduce the levels of risk in which they live, and facilitate their development in society. Specific objectives are to provide special attention to the female USWs, reduce sickness and drug abuse rates; improve nutritional habits; reduce the number of early pregnancies and modify harmful sexual practices; reduce illiteracy, school drop out and 
repetition rates; increase and diversify recreational practices; and, improve the capacity to access the labor market. Main strategies used by the Program to accomplish its goals are the development of a permanent educative process; access of USWS to health, educational and recreational services; organization of USWS and their families; and elevation of community conscience levels around the problem of underage work. The Program's educative approach preserves the liberty of USWs and leaves them free to make their own decisions. It takes into account their individuality, developmental process, experience and cultural background, and, uses non-conventional educational techniques and materials.

The Program is implemented in several phases, including an ongoing assessment of the situation of USWs in the intervention location and the training of a team. The work with USWs in the streets begins with an initial contact that is intended to gradually develop into a friendly and informal relationship, leading to an active involvement of USWs in the Program's activities.

The Program specifically addresses the four areas of health, education, recreation and job training. The health component, with a preventive approach, offers USWS permanent health follow-up, counseling, health education in sexuality, drug abuse, nutrition and illness 
prevention. The educational component provides access to educational services, school follow-up and special school reinforcement programs. The recreational component offers diverse and permanent recreational activities, and access to recreational services. Finally, the job-training component attempts to train USWs in some occupation, and foster and support small income-generating projects.

The Program's main successes, according to Landazuri's (1992) evaluation report, are the children's school achievement improvement and the community's raised consciousness and participation around the problem of child work (Landazuri, 1992). Other evaluation data show the following as some of the qualitative impacts accomplished by the Program: the development of an organizational process among USWs, the strengthening of their learning abilities, their increased use of available health centers, an increase in their recreational time, a decrease in the intensity of their work, an increase in their self esteem, and the prevention of uprooting children and turning them into street children (PTP, 1994a). 
WOMEN IN LATIN AMERICA

As indicated earlier, there is some evidence that female USWS encounter greater disadvantage and risk than do male USWs. At least some of their problems are qualitatively different from those of the boys, in part due to the lower societal position of women. Indeed the Program just described has focussed on the special problems of female USWs, and the present study has been designed to give special consideration to the gender issue.

Elson (1991), addressing women in developing countries states that:

...[the] emphasis [should be] on socially conferred capabilities - what are women in practice able to do? Are they able to be well-nourished, to enjoy good health and long lives; to read and write; to participate freely on the public sphere; to have some time to themselves; to enjoy dignity and selfesteem? how does women's enjoyment of these capabilities compare with that of men? Do women face constraints which are nor faced by men? In so far women enjoy fewer and more circumscribed capabilities than do men.... (Elson, 1991, p.5)

Latin America might well be envisaged as a patriarchal society where a mixture of indigenous, Spanish and modern urban cultures are intertwined and superimposed in a complex dynamic process (Lenero, 1980). In this patriarchal society, women's subordination and restricted role limit their freedom, autonomy and self confidence (Tenorio, 1992; Gissi, 1980; Safa, 1980). Their dependent and passive attitudes are a consequence of their 
oppressed condition rather than inherited characteristics, argue Nash (1980) and Safa (1980). Women learn their subordinate role at an early age (Safa, 1980); in the family (Nash, 1980; Safa, 1980), at church (Lindsey, 1990; Gissi, 1980), and in schools (Stromquist, 1989). Women themselves are important transmitters and reinforcers of traditional values and patterns (Gissi, 1980).

Women in Latin American societies still hold an inferior position regardless of their socio-economic status (Safa, 1980); it is the cultural and especially the religious beliefs, plus the general survival of feudal attitudes, that keep them in a subordinated condition, argues Lindsey (1990). This subordinated position of women in developing countries, as explained by Beneria and Roldan (1987), is the result of the interplay between class and gender; it is the patriarchal institutions and social relations that enforce the class system that place women in an inferior position where men are the breadwinners and women are the housekeepers and child raisers, though a large group of women work a double shift, that is, for wages and domestic tasks (Lim, 1983). In this context, Lim (1983) claims, equity for women can only be reached by a combined struggle against capitalism, patriarchy and imperialism through specific strategies to be undertaken in accordance with particular historical, social, economic and political conditions.

Relationships in Latin America are characterized by verticality and 
male dominance. Men commonly want submissive women, but at the same time despise their submission (Safa 1980). Women are seen as childlike and apolitical beings for whom life is circumscribed by family obligations and responsibilities, because being mothers and wives is expected to be their greatest fulfillment (Lobao, 1993; Gissi, 1980; Safa, 1980). However, Jaquette (1980) points out that Latin American women have a central and powerful role in the family; thus, she rejects the argument that portrays them as passive and weak. Latin American women, add Safa (1980) and lara and Safiotti (1980), establish strong bonds with their children and relatives and play an important role in the children's education, while men play only a marginal role. Furthermore, continues Safa (1980), women have been able to maintain considerable authority over their children and close relations with extended family and neighbors, which has prevented their seclusion in nuclear families. Despite the influential role women have played in the family, they do not enjoy the same decision-making power as men; their bargaining power is weaker, as usually men are in control of the resources (Elson, 1991).

The Catholic Church has also played an important role in the subordination of women, assigning them an inferior position, controlling their lives and sexuality, and reinforcing endurance and sacrifice as appropriate attributes to cope with their hardships (Carlson and Bond, 1990; Ruether, 
1983). However, adds Stromquist (1989), the grip of traditional Catholic ideas is weakening; middle and high class women face fewer restraints, though conditions for poor women remain largely unchanged (Jaquette, 1980). Significant differences can be observed between the attitudes of rural and urban lower class women, and those of urban middle and high class women (with the latter in each case being more progressive). Poor women face a double burden of class and gender, that is, low education, low income, few marketable skills and major domestic responsibilities (Lobao 1993). The disadvantaged position of women is revealed in most domains, but access to resources, jobs and education are especially salient, Afshar (1991) concludes.

\section{Women in Ecuador}

Ecuadorian women face constraints similar to most Latin American women $^{12}$, although some improvement in their conditions can be observed in the last two decades. Among these changes are the increasing access of females to education, and participation in the labor market (UNICEF/DYA, 1992). Perez (1987) shows that in 1974 , only $9.4 \%$ of women older than 6 years had completed high school, compared to $27.5 \%$ in 1985 . According

\footnotetext{
${ }^{12}$ The Ecuadorian government plan for the period 1984-1988 recognized the subordinated condition of women, and how they are discriminated against (CEISE, 1988).
} 
to UNICEF and DYA (1992), participation in the labor market by Ecuadorian wormen has increased in recent years; in 1982, 1 out of 5 workers was a woman, whereas by 1992, the proportion had changed to 1 in 4 . By 1990 , women represented $26.4 \%$ of the economically active population; moreover, if women who do domestic work were added, the rate increased to $51.4 \%$ (UNICEF/DYA, 1992). In spite of these changes, the role of women in the household has not evolved (Moser, 1989; Perez, 1987); domestic chores are still their sole and primary responsibility. Working for wages outside the home has been added to the former traditional role as a sort of complementary activity to contribute to the family's income (CEISE, 1988). In fact, there is some evidence that female work is mostly related to family functions; UNICEF and DYA (1992) observed that $70 \%$ of the at-home workers were women. Furthermore, $92 \%$ of workers in domestic service are women (UNICEF/DYA, 1992). Whether household related or not, Ecuadorian working women contribute $48.5 \%$ of the family income, though the percentage of women's contribution decreases as the household income increases (UNICEF/DYA, 1992).

Poor working women face double exploitation for belonging to a lower social class and for being female. They are submitted to a harsh division of labor at home; they must bear societal prejudices against them and their positions, and receive little or no recognition for their income generating 
activities, as well as suffer disadvantaged working conditions such as lower wages, low skilled jobs and fewer employment opportunities (CEISE, 1988). Poor women must cope with overwhelming burdens; a study in an urban low-income community in an Ecuadorian city (Moser, 1989) found that women worked 12 to 18 hours per day in both paid and unpaid activities (unpaid participation here refers mostly to provision of basic community services). This overburden of work is forcing them to allocate increasing amounts of the housework to their elder daughters, who in turn have less time for school. According to Moser (1989), some of these women were able to handle such extreme distressful situations better than others:

In about $30 \%$ of the 141 surveyed, women were managing to cope; in about $55 \%$ women were just hanging on, mortgaging the futures of their sons, and especially their daughters, in order to survive; in about $15 \%$ women were exhausted, their families disintegrating, their children dropping out from school and roaming the streets, becoming involved in street gangs and exposed to drugs (Moser, 1989, p.180).

Most of the poor working girls, similar to their mothers, perform domestic work or occupations that are an extension of it. However, Garcia and Hernandez (1992) continue, in recent years, participation in the service area has decreased, while participation in retail sales activities has increased. Most girls stay in these two occupational areas all their lives; Garcia and Hernandez (1992) report that only two out of 10 women older than 18 years work in a different field. By age, girls 6 to 14 years typically 
work in domestic work or related jobs, and in small commercial activities, whereas, most of the 15 to 17 years old girls work in the service area, and very few are able to get a position in a factory or craft workshop (Garcia and Hernandez, 1992). Female underage workers are clustered in service and retail sales jobs while the boys have a broader range of choice (construction, crafts, manufacturing) (Garcia and Hernandez, 1992; UNICEF, 1992). Regarding income, female USWs are also disadvantaged; $80 \%$ of the girls made less than minimum wage while only $31 \%$ of the boys received less than minimum wage (Garcia and Hernandez, 1992).

Rooted cultural notions about the sexual division of work view male but not female underage participation in the labor market as appropriate, even though the number of urban boys and girls aged 6 to 14 are similar (INEC, 1991). Ecuadorian parents interviewed by Garcia and Hernandez (1992) concerning the issue of female/male underage work commonly said that boys should work because they are born to work, are stronger and have more character; that female work is much more dangerous because girls are weaker; that maybe they can work by age 15 when they are able to think; and that work outside the home is bad for girls because they are likely to lose their virginity as a result (Garcia and Hernandez, 1992). 


\section{EDUCATION AND GENDER}

Literacy and education are increasingly viewed in Latin America as necessary to improve women's status and employment opportunities (Acosta, 1989). In the last decade, most countries have made substantial efforts to expand educational services (Population Reference Bureau, 1986; Shiefelbein, 1985); however, disparities are found from country to country, from region to region within national borders, and among various social and economic sectors. School enrollment and literacy still continue to be serious problems in the rural areas of Central America and the Andean countries where indigenous population are prevalent (Acosta, 1989).

\section{Education in Ecuador Todax}

Ecuador, like many countries in Latin America, has notably extended its educational services (Shiefelbein, 1985); $96 \%$ of the 6 to 11 year old population is enrolled in school (Presidencia, 1992d). Nevertheless, educational levels of the population are still considered low; average length of schooling is 5 or 6 years, with a high percentage of students not completing elementary school, and many not continuing on. In spite of the expansion in the provision of educational services, the quality of education, according to some, has not improved (Presidencia, 1992e; Shiefelbein, 1985); school failure, level repetition and drop out rates are high and usually 
under-reported (Shiefelbein, 1985); 78\% of the enrolled students are at least one year behind their age group (Presidencia, 1992d). Students require an average of 7.7 years to complete elementary school (1.2 years per grade). Dropping out generally starts at age 10 and increases significantly between age 11 and 12 (Presidencia, 1992d); elementary school retention rate is $57 \%$, which means that only 57 out of 100 enrolled students finish elementary school (Delgado and Rivadeneira, 1992).

For underage workers the situation is even more difficult because work interferes with their education (Guerra and Lorant, 1991). Several studies report on the educational disadvantage of underage workers. UNICEF/OIT (1994) shows that the relationship between school attendance and underage work is noticeable; children who work attend school less than those who do not work (and $61.6 \%$ of the $10-14$ year old children and $74.4 \%$ of the $15-17$ year olds who are not in school, work). UNICEF/DYA (1992), in their study on urban underage workers, found that $26.6 \%$ of the 12-14 year olds attended high school, $49.1 \%$ of them had completed elementary school and did not go on, and $5.5 \%$ of them had no education. Tapia (1984) found that $86 \%$ of his sample of underage student workers in two locations in the country were educationally delayed. Cuvi et al. (1989) found $48 \%$ of USWs aged 6 to 17 in their sample were not attending 
school ${ }^{13}$. Rodriguez (1993), Garcia and Hernandez (1992) and Cuvi et al. (1989) state that the trend with underage workers is at the most completion of elementary school; few continue their education. Marquez (1990) found that 5 out of 10 underage workers had failed and repeated at least one level; that their drop out rates were high; and, that they had learning difficulties in the areas of math, grammar and sciences. Additionally, it has often been found that the children's working schedules are incompatible with their studies (UNICEF/DYA, 1992; Salazar, 1989). Teachers interviewed by Rodriguez (1993), confirmed the lower attendance and achievement of underage workers compared to non-working children. Salazar (1989) and Tapia (1984) found lower attention and concentration levels at school for USWs; school failure, states Tapia (1984), produces high levels of frustration in USWS and erodes their motivation to continue attending school.

\section{Education and Women in Latin America}

The tendency in education in Latin America is toward gender parity, reports Stromquist (1992); the female illiteracy rate is $19 \%$ while the males' is $15 \%$; enrollment differences are minimal at the primary and secondary

\footnotetext{
${ }^{13}$ Cuvi et al. (1989) report that school attendance decreases as age increases; they found that $81 \%$ of the $14-17$ year old USWs in their sample did not attend school, and $68.8 \%$ were 2 or more years educationally delayed.
} 
levels, but become pronounced at the university level (Stromquist, 1992; Acosta, 1989). Nash (1980) reports that women represent less than half of the population at universities and that the proportion of female illiteracy is on the increase. Fink and Arnove (1989)'s findings contrast with the argument of gender parity in school attendance; they found that one out of every four adult women is illiterate (a slightly higher rate than other reports) and that only $65 \%$ between the ages of 5 and 19 are in primary or middle school. Data on elementary school failure indicate that the percentage of girls failing and repeating a level is the same or slightly less than it is for boys (UNESCO, 1988). But, females tend to drop out in larger number than males (Stromquist, 1992).

According to Young (1988), the conditions of women have improved some but their position relative to men has worsened. Traditional ideas about the education of women still prevail; it is still not uncommon for parents to choose to send their sons to school rather than their daughters, especially when they cannot afford to send both (Elhers,1990; Acosta, 1989; Stromquist, 1989; Population Reference Bureau, 1986; Charlton, 1984; Nash, 1980). All in all, states Stromquist, (1993) little is known about the substantive education of Latin American women, as it is a topic that has remained relatively unexamined.

Specific data about the educational situation of women in Ecuador 
follow the pattern reported by Stromquist; overall, there are few gender differences at the elementary and high school levels (INEC, 1991d). However, illiteracy rates are still higher for women than for men $160 \%$ of the illiterate are women [Presidencia, 1992d, UNICEF/DYA, 1992]) ${ }^{14}$, and university enrollment is lower for females than males (INEC, 1991d; Perez, 1987). The education of women in Ecuador is often still influenced by traditional ideas ${ }^{15}$.

Regarding the educational situation of female underage workers, the study by CEDEJOTA/UNICEF (1989) on USWs who attend school in the evening found higher repetition rates for females than for males. Garcia and Hernandez (1992) found considerable differences in school attendance between female and male underage workers; only $33.3 \%$ of the girls went to school compared to $70 \%$ of the boys. They also report that a considerable number of girls exclusively perform domestic chores and do not go to school ${ }^{16}$, however their work is not recognized as such. Finally, Novillo (1994), in her study of the USWs" family situation, established that the

\footnotetext{
${ }^{14}$ The overall illiteracy rate for the country is $9.8 \%$ (INEC, 1991).
}

${ }^{15}$ UNICEF/DYA (1992) found that in non-Spanish-speaking Indian communities, it is usually the male who learns Spanish and therefore has the possibility of learning how to read and write, while women stay at the margin of literacy programs (UNICEF/DYA, 1992). To cope with this situation the country has developed bilingual educational programs for the non-Spanish-speaking (Shiefelbein, 1985).

${ }^{16} \mathrm{Garcia}$ and Hernandez (1992) report that $7.5 \%$ (92,592) of children do not work, do domestic chores and do not go to school. Most of them are girls, they say, because $90.6 \%$ of the children who do only domestic chores are females. 
USW' mothers have less schooling than their fathers.

Another study addressing the educational situation of the female underage workers, reports that the girls' school achievement is affected by the discriminatory treatment of teachers, who orient students towards gender "appropriate" careers (UNICEF and DYA, 1992). Finally, Moser (1989) argues that poor girls have less time for school work because of the overburden of their domestic responsibilities, due to their mother's involvement in economically productive activities.

Education: Advantages and Disadvantages for Women

Despite the increasing access Latin American women have to educational services, most of them:

...still face the limitations imposed by the patriarchal tradition and a sexist culture that circumscribes their choice of profession, their employment opportunities and salaries, their role within the family, and their control over their own well being. (Acosta, 1989, p.118).

Fink and Arnove (1989) report that women's average educational attainment is consistently lower than that of men in most Latin American countries, and in some cases there has been a deterioration. Furthermore, Fink and Arnove (1989) argue that the progress made in the education of women in the seventies was reversed by 1985 with the impact of economic 
crisis. Stromquist (1989) and Nash (1980) stress the point that the disadvantage of women in education is shaped not only by economic conditions but also by patriarchal ideologies that control women. It is related to a discriminatory structural condition in society that produces a pervasive set of disadvantages for women, argues Young (1988). Therefore, education is not an independent solution to women's issues because inequity is ingrained in the system (Jaquette, 1990; Bourque and Warren, 1987).

Critics have faulted education for promoting traditional values (UNICEF/DYA, 1992); being a reproducer of the dominant ideology (Stromquist, 1992; Boserup, 1990); stereotyping women through texts (Stromquist, 1992); leading women into domestic roles (Braslavsky, 1992); segregating by class ${ }^{17}$ (Stromquist, 1992); having little impact on poor women, as it is mainly middle and high class women who benefit from increased educational opportunities (Nash, 1980; Safa, 1980); and, being negatively related to jobs in the informal sector (Berhman and Wolfe, 1979).

Regardless of these arguments, several benefits for women are clearly associated with education: reduced infant mortality and fertility rates (Cochrane, 1983; Levine, 1983), enhanced child nutrition (which indirectly affects women) (UNICEF/DYA, 1992), better income-generating

\footnotetext{
${ }^{17}$ In Latin America, public schools have fewer resources than private ones, and are the site for the education of poor people (Stromquist, 1992).
} 
opportunities (Engle, 1983); slightly higher social status (Bourque and Warren, 1987), and increased opportunities for stable employment (Catanzarite, 1992; Fink and Arnove, 1989) and upward mobility (Population Reference Bureau, 1986). Furthermore, notes Afshar (1991), education, organization and resistance provide the means to struggle against poverty and subordination.

The impact of the current educational efforts in the population are uncertain, claim Nash (1980) and Stromquist (1989), yet it seems that education has a double-edged character: education stereotypes women; however, illiterate women are more likely to uphold traditional assumptions about women's roles and pass them onto their daughters. Moreover, education may reproduce existing gender relations; yet women require certain levels of formal education to attain better jobs. Improvement in the educational background of women is needed if long term changes are to be attained in developing countries, though, increasing women's opportunities to education does not necessarily improve their status. Finally, both Tinker (1990) and Acosta (1989) agree that while access to education is imperative to enhance women's opportunities, its structure and content need to be altered. 
Some Notes on Educational Change.

Qualitative educational experiences for women need to reflect the reality in which they live. Latin American educator, Paulo Freire (1985; 1973 ) is a strong supporter of education as a instrument of change in society. Within a Marxist framework that takes into account gender, race and age, in addition to class, he proposes a pedagogy for the oppressed. This pedagogy is based on a dynamic and even relationship between learner and educator. It promotes an exchange of experiences aimed at developing an inquisitive and critical attitude towards the subject that is being studied, in order to re-create it. The whole process points to consciousness raising by relating what is being studied to the concrete living situation of the participants. For Freire, the awareness gained through the educative process he proposes should lead people to get organized and search out alternative options for their living situations. From this perspective, Freire continues, school is but one of a myriad of learning experiences, and frequently limited to the transmission of information and reproduction of established values. Gomez Da Costa (1989), following Freire's approach, understands education as a process that provides a wide range of experiences for the learner. This approach, continues Fink and Arnove (1989), does not deny the differences among the participants in the educative relationship, but attempts to eliminate the power component. 
Different social problems, such as those of impoverished women and those of children in and of (USWs) the streets, have been addressed in Latin America using Freire's approach, as an alternative intervention to those stressing social control (Lusk, 1988). It is within this frame of reference that Programa Trabajadores Prematuros provides a series of educational opportunities to USWs -- one of them, access and support through school-with a strong emphasis on gender issues. 


\section{CHAPTER III}

\section{METHODOLOGY}

This research project was designed to examine the educational behavior (attendance and achievement) of Ecuadorian USWs who participate in an underage workers program, and to look at variations by gender, location and age. The hypotheses were the following: (1)The rate of school attendance will be lower for female USWs than for male USWs; (2)The rate of school achievement will be lower for female USWs than for male USWs; (3)school attendance and achievement will vary by gender, location and age.

\section{The Variables $^{18}$}

The dependent variable is the school behavior of USWs, as measured by school attendance and achievement of the sample subjects within an 18 months period. Their educational situation was determined by an initial evaluation and three follow-up evaluations (6 months apart).

The Ecuadorian educational system has 4 levels: pre-school,

${ }^{18}$ For the variable code book, see Appendix A. 
elementary school (6 years), secondary school (6 years) and higher education. The secondary level is divided into two levels: basic studies and specialization. In both levels of secondary school students can choose between studies that will train them for specific jobs or prepare them to go to the university. The country's educational system consists of both public and private schools. The former, mostly attended by poor people, are supported by the government, but still students have to pay registration fees, school materials, uniforms and transportation (Presidencia, 1991d; UNICEF/DYA, 1992).

School attendance refers to whether or not the child was going to school at the time of the evaluation.

School Achievement refers to the child's performance at school and uses the same evaluation categories as the ones employed by the Program $^{19}$.

The categories used to evaluate the USWs' school achievement are based on the average grades given them by the school (excellent, good, average, fair and poor). This average grade provides a general view of the USWs' school performance per term. The conversion to the A - F system was used to show the closest possible translation of the Ecuadorian grading system into the one used by the United States:

\footnotetext{
${ }^{19}$ The categories used by the Program follow the Ecuadorian school evaluation system.
} 
(1) Excellent achievement: Corresponds to an A

(2) Good achievement: Corresponds to a B

(3) Average achievement: Corresponds to a C

(4) Fair achievement: Corresponds to a D

(5) Poor achievement: Corresponds to an F

It is important to mention that records of the school achievement of high school children are not kept in the Program's national follow-up system. When the information system was designed, it was assumed that access to teenagers would be very limited, as they are often not willing to give this kind of information. This assumption was partially correct. During the operation of the Program it has been a fairly common experience in the local programs to find a reluctant attitude in teenagers when they were asked if someone from the team could visit their school to ask about their grades. As a result there are no data on the school achievement of high school students.

Follow-up refers to the time during which school attendance and achievement of USWs were evaluated for the present study. Initially, it was planned to be longer ( 24 to 30 months). However, the data base from which the information was drawn had not been updated, consequently there were few records of, subjects with five or six evaluations (24 to 30 month follow-up period). Thus, the researcher 
decided to select all those subjects who had at least four evaluations, that is, an 18 month follow-up phase preceded by the initial measurement.

Independent Variables

Gender refers to female/male.

Location refers to the city or town where the sample subjects live and work.

Age refers to the age of the sample subjects at the time of their entry into the Program.

\section{The Sample}

The sample of USWs affiliated to Programa Trabajadores Prematuros of Ecuador was chosen because: (1)It is a large sample of convenience (the Program from which the sample was drawn is the largest in the country providing care for this population (Presidencia, 1992a; UNICEF, 1990); (2)it is the only group of children who work on the streets about whom systematic information is available; and (3)it is the only population that has been followed for an extended period of time (since 1990).

In an attempt to get a broader picture of the problem, sample 
subjects were selected from different local programs in different cities in the country. As these local programs are not completely analogous, comparable local programs were selected first, while the sample subjects were chosen subsequently.

The criteria for selecting local programs that would allow comparisons among them were the following: (1)Same year of implementation; (2)application of similar educative methodology; (3)systematic follow-up data.

The local programs in the cities of Otavalo, Ambato, Cuenca, Ibarra and Riobamba met these criteria. Out of these five programs, three that vary by city size, size of the USW population, illiteracy rates, amount of urbanization, and working occupational base, were chosen. The literature says that there are differences in the USW's conditions by city size and size of the USW population; therefore, cities were selected to provide information about this (Novillo, 1994).

On the basis of these criteria, the cities of Cuenca, Ambato and Otavalo were selected. Before describing the main characteristics of these sites, I would like to present a quick overview of Ecuador's geographic conditions and administrative division.

Ecuador is located in western South America, bordering the Pacific Ocean at the Equator between Colombia and Peru. It is crossed by the 
Andes that divide the country into three distinct regions: the lowlands -coastal plain terrain- situated between the seashore and the western range of the Andes; the inter-Andean central highlands; and, the Oriental or Amazon Region located east of the Andes. Finally, a fourth region of the country is constituted by the Galapagos Islands. Over half of the Ecuadorian population is 'mestiza' (a mixture of Indian and Spanish) and a quarter of it is Indian, while $10 \%$ are black and $10 \%$ white. The two largest cities in the country are the capital city --Quito-- located in the highlands, and Guayaquil --the most important sea-port-- located in the lowlands.

Administratively, the country is divided into 21 provinces; each of the sample sites belongs to a different one. According to census data some of the demographic indicators of the sample sites are:

Qtavalo. It is a small rural town, located in the highlands in the northern part of the country. It has 56,286 inhabitants and a population density of 112.8 per $\mathrm{Km} 2$. This town comprises only $21 \%$ of the province's population, most of whom work as laborers, drivers, small businessmen and petty vendors. The illiteracy rate is $16 \%$ for the province, and $26 \%$ for the town (INEC, 1991a).

Cuenca. It is the third largest city in the country and shares some of the characteristics of the 2 largest cities of the country (Quito and 
Guayaquil), such as better levels of education and lower illiteracy rates (9\% for the city and $\mathbf{1 1 . 9}$ for the province). Cuenca is located in the highland region in the southern part of the country. It has a mainly urban population of 331,028 inhabitants, which comprises more than $60 \%$ of the province's population and has a population density of 105.8 per $\mathrm{Km} 2$. The bulk of the population is involved in professional or semi-professional activities (INEC, 1991c).

Ambate. It is located in the central part of the country in the highland region. It is a medium sized city of 227,790 inhabitants that comprise $60 \%$ of the province's population, and has a population density of 228 per $\mathrm{Km} 2$. Illiteracy rate for the province is $12 \%$, and for the city, $11 \%$. Most of its population is urban, and mainly involved in commercial activities (INEC, 1991b).

Once it was determined that the local programs fulfilled the established criteria, all boys and girls who had participated in them for at least 18 months were included in the sample.

Recapitulating, the universe of the study is the population of children between 5 and 17 years of age who work on the streets and are affiliated with one of three local programs of Programa Trabajadores 
Prematuros $^{20}$. A sample of 413 girls and boys, comprised of those who have participated in the Program for at least 18 consecutive months in one of the three locations mentioned, was drawn from it.

\section{Data Collection}

The data were drawn from the Information System of the Program because: (1)This system registers information about the children; (2)the population of USWs is not easily approachable; (3)when approached, these children frequently give inaccurate information ${ }^{21} ;(4)$ these data are considered more reliable than those from interviews with the children, administered by an unfamiliar researcher might be, because they were collected by the Program's educators who had built a close relationship with each child and her or his family. Therefore, the data could be checked and re-checked when interviewing the parents, when visiting homes or school, when observing the kids in different situations, or because the child, when she or he trusted the educator, willingly provided information.

${ }^{20}$ The Program increased its coverage every year; in 1990 it provided care for 5,000 USWs, in the following two years it doubled its coverage, and by June 1994 provided care for 12,430 USWs (Programa Trabajadores Prematuros, 1994a).

${ }^{21}$ This is a population that suffers high levels of abuse and, therefore, distrusts any person that approaches them (except for relatives, acquaintances and peers ). One of the strategies they use to protect themselves is giving false information (Ritter, 1988). 
The Program designed its own information system ${ }^{22}$ in order to be able to measure its impact on the target population and to monitor its actions by determining: (1)Changes that occurred in the life situation of the minors in the areas of health, education, recreation and job training; (2)the magnitude of the changes; and (3)the causes of the changes. Impact is evaluated by a comparative analysis between the base line, that is, the description of the child's situation when she or he begins to participate in the Program, and the semestral evaluations.

The follow-up system includes 21 forms. Eighteen of them are processed and used by the local teams for planning and follow-up activities. The other three are sent to the national system and entered into a general data base for the follow-up and analysis of the Program's impact at a national level (INNFA, 1991b). To measure impact, these forms evaluate three different aspects: The conditions of USWs once every semester; the activities carried out by the Program in each component, monthly; and, the educators's performance, monthly. To assess the conditions of USWs, the following indicators are taken into account: (1)Health: presence/absence of sicknesses, nutritional habits, drug and alcohol consumption habits, use of contraceptives,

\footnotetext{
${ }^{22}$ Taking into account that in countries like Ecuador updated computer technology is not easily accessible, I consider it worthwhile to talk briefly about the information system designed by this Program, which even though questionable, is an interesting attempt to systematize data for this kind of population.
} 
presence/absence of pregnancies and/or abortions; (2)education: school attendance and achievement; (3)recreation: time spent in recreational activities in and outside the Program; (4)labor: working schedules and number of hours worked per day; (5)family: where and with whom the child lives.

The data for this study were drawn from the general data base mentioned above, and include the following information for each sample subject: name; code number; base line age; age at the end of follow-up period; gender; city of residence; school attendance at the base line, plus three semestral evaluations; and school achievement of USWs attending elementary school ${ }^{23}$ at the base line, plus three semestral evaluations.

\section{Data Analysis}

Frequencies and cross-tabulations were used to examine variations by gender, location and age in the school attendance and achievement of USWs. Additionally, the base line was compared with the most recent evaluation, to determine changes in the educational behavior of the sample in the 18 month follow-up period.

\footnotetext{
${ }^{23}$ As mentioned earlier, the Program does not enter into the general data base the achievement of high school USWs (INNFA, 1991b).
} 


\section{CHAPTER IV}

\section{THE FINDINGS}

\section{CHARACTERISTICS OF THE SAMPLE}

\section{Location}

The distribution of the sample by location is as follows: $54 \%$ of the subjects are from Ambato, $30 \%$ from Cuenca, and $16 \%$ from Otavalo. The different percentages for each location are related to the size of the population of underage workers covered by Programa Trabajadores Prematuros in each city, which in turn reflects the size of the total population of children working in the streets found in that location. That is to say, cities with larger populations of USWs had a local program with broader coverage ${ }^{24}$. In the present study, Ambato, with 1,182, exhibits the largest population of USWs of the three locations, followed by Cuenca with 580 , and Otavalo with 128 (PTP, 1990a).

Since the usual pattern is that larger populations of USW are found in bigger cities (Cuenca in this study), it is interesting to notice that Ambato has the largest number of USWs. This might be related to the characteristics

\footnotetext{
${ }^{24}$ The Program assessed the problem of the USW population in particular cities before launching local programs.
} 
of these locations: Cuenca has a considerable population involved in professional or semi-professional activities, whereas Ambato exhibits extended commercial activity (INEC 1991b,c), part of which takes place in the streets, plazas and open markets. This circumstance presumably provides the working children with more opportunities to develop their economic activities --trading in the streets, plazas and markets of the cities-- (Novillo, 1994; Garcia and Hernandez, 1992). According to local Program notes, it was common for the staff of the local program in Ambato to contact USWs from surrounding towns. Additionally, in Ambato USWs referred that they had more working opportunities in Ambato than in other nearby towns.

\section{Gender}

Sixty three percent of the sample is male and $37 \%$ is female (see Table 1). This distribution reflects moderately the composition of the population of USWs in the country, where $71 \%$ are male and $29 \%$ are female (PTP, 1990a). The smaller percentage of girls is likely to be associated with the general view in South America that working in the streets is mainly a male activity, and thus parents resist allowing their daughters to work in the streets (Boyden, 1988; Mancilla, 1988; Bernal and Ayala, 1985; Piloti, 1985) Regardless of this view, during the last few years females' rate of participation has increased (Garcia and Hernandez, 1992; UNICEF/DYA, 1992; Elson, 1991); it is possible that this norm has weakened, and/or that the increased poverty levels of the last 
decade are pushing girls to the streets (MTRH et al. 1994; Novillo, 1994; Moser, 1989; Yopo, 1989; Piloti, 1985).

When looking at the national distribution of USWs, that is, when

\section{TABLE 1.}

SAMPLE DISTRIBUTION BY GENDER AND LOCATION

\begin{tabular}{|l|c|c|c|c|c|c|}
\hline \multirow{2}{*}{ LOCATION } & \multicolumn{2}{|c|}{ MALES } & \multicolumn{2}{c|}{ FEMALES } & \multicolumn{2}{c|}{ TOTAL } \\
\cline { 2 - 7 } & No. & $\%$ & No. & $\%$ & No. & $\%$ \\
\hline OTAVALO & 38 & $58.5 \%$ & 27 & $41.5 \%$ & 65 & $100 \%$ \\
\hline AMBATO & 165 & $74 \%$ & 58 & $26 \%$ & 223 & $100 \%$ \\
\hline CUENCA & 56 & $45 \%$ & 69 & $55 \%$ & 125 & $100 \%$ \\
\hline TOTAL & 259 & $63 \%$ & 154 & $37 \%$ & 413 & $100 \%$ \\
\hline
\end{tabular}

comparing the populations in the cities from the highlands with the ones in the lowland cities, meaningful gender differences can be observed: $44 \%$ of the USWs in the highlands are females and $56 \%$ males; in the lowlands, $16 \%$ are female and $84 \%$ are males (Novillo, 1995). The gender variations reflect the cultural and social differences of both regions, and help to explain the distribution patterns of this population. One interpretation addressed by Tarazona-Sevillano (1992), Andreas (1992) and Marks (1992), involves the somewhat more ample and egalitarian participation of women in productive activities in the Andean communities; another one has to do with the 
conception in Andean cultures of work experienced as part of the socialization process of children, and therefore not detrimental to children's development (Boyden, 1988).

Taking into account that the three sample populations are located in cities in the highlands, it is understandable (see Table 1) that the Otavalo and Cuenca sites have a notable female population: in Otavalo $42 \%$ are females, and in Cuenca there are more girls (55\%) than boys ( $45 \%)$. However, Ambato doesn't follow this trend; it has a large male USW population (74\%) which is closer to the national or the lowlands average, than to the (highlands) regional one. Furthermore, when comparing the gender distribution of the overall USW population of each city: Cuenca: $50 \%$ males, $50 \%$ females; Otavalo: $57 \%$ males, $43 \%$ females; and, Ambato: $62 \%$ males, 38\% females (PTP, 1990a) with the sample's distribution, the location of Ambato shows the largest difference. This bias is probably due to the fact that the local program staff hired had already been carrying out activities with male child workers ${ }^{25}$ in this location and continued to work with them once the Program was launched (INNFA-UNICEF, 1987).

Age

The sample's average age is 10 years and the majority of the children

${ }^{25}$ A local organization funded by INNFA and UNICEF worked with USWs in Ambato before Programa Trabajadores Prematuros was implemented. 
are younger than 12 years old; $68 \%$ are within the 5 to 11 age category, while $32 \%$ are 12 to 17 (see Table 2). When breaking the sample into three age groups: $5-9$ years; $10-12$ years; and $13-17$ years, $80 \%$ of it is clustered within the 5 to 12 age category. One possible explanation for this bigger group of younger USWs is the consistent growth of the younger group of workers (Garcia and Hernandez, 1992; UNICEF/DYA, 1992), probably associated, again, with the increasingly stressful economic conditions that force families to use the labor of as many able members as possible (Wright et al., 1993; UNICEF/DYA, 1992; Mancilla, 1988). It might also be associated with the fact that the younger children don't have other ways of making money (work is forbidden for children under $12^{26}$ ), than working in the streets ${ }^{27}$. The streets offer this age group working opportunities which --even though illegal-require almost no training and no employer, in most cases.

Additionally, these working activities are flexible; they usually have no fixed schedules (which allows minors to match them with domestic tasks and sometimes with school), and can easily be combined and even switched from

${ }^{26}$ According to the Ecuadorian law for minors, work under 14 years is prohibited except for youth between 12 and 14 who are allowed to work basically as apprentices with special permission of the Court and under conditions that will not endanger their health or educational process (Registro Oficial, 1992, Art. 155-156-157).

${ }^{27}$ Compared to the younger children, youth older than 12 have working options other than the street activities: boys mostly as apprentices in different areas (construction, mechanics, carpentry, shoe repair, crafts, and the likel, and girls mostly in domestic service (Garcia and Hernandez, 1992). 
one to another (Boyden, 1988). Observations have shown that some boys shine shoes at certain times of the day and sell newspaper at others; the children who sell switch products depending on what sells best; others, while shining shoes, sell candy to the client. Still, when the weather or other circumstances do not allow them to develop their working activities, they come up with some alternative option that will produce the money they need to bring home.

This quick, imaginative and creative attitude of the working children never ceased to amaze the Program's staff; the following anecdote might illustrate this point: There was a strike in Ambato and the students were struggling with the police in the city's main square and its surroundings (USWs' usual working area); the students were throwing stones and the police attempted to control the situation with gases. Under these circumstances the UWSs couldn't carry out their usual activities; however, to our surprise, they collected stones and sold them to the students in order to make some money for the day.

The distribution of age by gender categories suggests that the boys work in the streets for a longer span of time than the girls: only $23 \%$ of the female USWs are 12 to 17 years old, compared to the $38 \%$ of male USWs. Additionally, the distribution denotes an early incorporation of the female USWs, as $77 \%$ of the females are in the younger age category (see Table 2 ). 
TABLE 2.

AGE OF THE SAMPLE BY GENDER

\begin{tabular}{|l|c|c|c|c|c|c|}
\hline \multirow{2}{*}{ AGE } & \multicolumn{2}{|c|}{ MALES } & \multicolumn{2}{c|}{ FEMALES } & \multicolumn{2}{c|}{ TOTAL } \\
\cline { 2 - 7 } & No. & $\%$ & No. & $\%$ & No. & $\%$ \\
\hline 5 TO 11 & 161 & $62 \%$ & 119 & $77 \%$ & 280 & $68 \%$ \\
\hline 12 TO 17 & 98 & $38 \%$ & 35 & $23 \%$ & 133 & $32 \%$ \\
\hline TOTAL & 259 & $100 \%$ & 154 & $100 \%$ & 413 & $100 \%$ \\
\hline
\end{tabular}

Regarding, the age of the sample by location, Cuenca has the youngest group; $87 \%$ of the subjects are within the younger age category (see Table 3). Ambato and Otavalo exhibit more even distributions: almost $60 \%$ of their populations are within the 5-11 age category and $40 \%$ are in the 12 17 age category.

TABLE 3.

AGE OF THE SAMPLE BY LOCATION

\begin{tabular}{|l|c|c|c|c|c|c|c|c|}
\hline \multirow{2}{*}{ AGE } & \multicolumn{2}{|c|}{ OTAVALO } & \multicolumn{2}{|c|}{ AMBATO } & \multicolumn{2}{c|}{ CUENCA } & \multicolumn{2}{c|}{ TOTAL } \\
\cline { 2 - 9 } & No. & $\%$ & No. & $\%$ & No. & $\%$ & No. & $\%$ \\
\hline 5 TO 11 & 39 & $60 \%$ & 132 & $60 \%$ & 109 & $90 \%$ & 280 & $70 \%$ \\
\hline 12 TO 17 & 26 & $40 \%$ & 91 & $40 \%$ & 16 & $10 \%$ & 133 & $30 \%$ \\
\hline TOTAL & 65 & $100 \%$ & 223 & $100 \%$ & 125 & $100 \%$ & 413 & $100 \%$ \\
\hline
\end{tabular}




\section{SCHOOL ATTENDANCE}

The literature on school attendance of underage workers states that frequently the intensity and conditions in which these children work affect their educational process (UNICEF/OIT, 1994; Wright et al., 1993; Garcia and Hernandez, 1992; Boyden, 1988; Mancilla, 1988), and place them in a disadvantaged position from early ages (Presidencia, 1992a). As described earlier, research done in Ecuador points to several characteristics of USW'' school attendance by gender (Garcia and Hernandez, 1992); location (Novillo, 1994); and age (Cuvi et al., 1989). This study supports some of these findings: differences by gender, location and age were found, as hypothesized. However, the hypothesis that the rate of school attendance would be lower for female USWs than for male USWs was not supported.

In this section, I will examine school attendance of the sample subjects. I will start with a general account of USWs' school attendance, followed by a more detailed description of it by gender, location and age. The data will be presented by comparing the initial with the most recent follow-up. The two intermediate evaluations won't be taken into account for this analysis because they don't provide additional information; they show no or minimal variations.

The overall school attendance rate of USWs did not change during the 18 month follow-up period; at both times, $65 \%$ were going to school while $35 \%$ were not (see Table 4). By far, more children were going to elementary 
TABLE 4.

SCHOOL ATTENDANCE: BASE LINE AND FOLLOW-UP

\begin{tabular}{|l|c|c|c|c|}
\hline \multirow{2}{*}{$\begin{array}{l}\text { SCHOOL } \\
\text { ATTENDANCE }\end{array}$} & \multicolumn{2}{|c|}{ BASE LINE } & \multicolumn{2}{c|}{ FOLLOW-UP } \\
\cline { 2 - 5 } & No. & $\%$ & No. & $\%$ \\
\hline ATTEND ELEMENTARY SCHOOL & 261 & $63 \%$ & 228 & $55 \%$ \\
\hline $\begin{array}{l}\text { DO NOT ATTEND ELEMENTARY } \\
\text { (elemeOt }\end{array}$ & 85 & $21 \%$ & 75 & $18 \%$ \\
\hline $\begin{array}{l}\text { ATTEND School not completed) } \\
\text { DIGH SCHOOL }\end{array}$ & 10 & $2 \%$ & 44 & $11 \%$ \\
\hline $\begin{array}{l}\text { (elementary School COMpleted) } \\
\text { TOTAL }\end{array}$ & 57 & $14 \%$ & 66 & $16 \%$ \\
\hline TOTAL & 413 & $100 \%$ & 413 & $100 \%$ \\
\hline
\end{tabular}

school than to high school at both the first and last evaluation. This is partially related to the young age of the sample but also to their being educationally delayed in school (Presidencia, 1992a; DYAUNICEF, 1992). At the beginning, almost two thirds of the sample were going to elementary school and a minimal $2 \%$ attended high school. Of the $35 \%$ who did not go to school, $21 \%$ had not completed elementary school and did not attend school, and $14 \%$ had completed elementary school but did not attend high school. At the base line, none of the sample subjects had completed high school. 
By the end of the follow-up period, slightly over half of the USWs attended elementary school, $11 \%$ went to high school, and $34 \%$ were not registered in school. Of the group not registered in school, $17 \%$ had not completed elementary school and did not attend it, while the other $17 \%$ had completed elementary school and were not going to high school. During the measurement period, none of the USWs completed high school.

An outstanding characteristic of the sample was their low percentage of high school attendance at both evaluations (see Tables 5 and 6), though it increased considerably at the last one. Sixty seven subjects had completed elementary school at the base line, and only $15 \%$ of them had gone on to high school, whereas, by the follow-up, 110 children had completed the elementary level and $40 \%$ of them attended high school. 
TABLE 5.

ELEMENTARY SCHOOL: BASE LINE AND FOLLOW-UP

\begin{tabular}{|l|c|c|c|c|}
\hline \multirow{2}{*}{$\begin{array}{l}\text { ELEMENTARY } \\
\text { SCHOOL }\end{array}$} & \multicolumn{2}{|c|}{ BASE LINE } & \multicolumn{2}{c|}{ FOLLOW-UP } \\
\cline { 2 - 5 } & No. & $\%$ & No. & $\%$ \\
\hline ATTEND & 261 & $75 \%$ & 228 & $75 \%$ \\
\hline DO NOT ATTEND \\
(elementary school not completed)
\end{tabular}

TABLE 6.

HIGH SCHOOL ATTENDANCE: BASE LINE AND FOLLOW-UP

\begin{tabular}{|l|c|c|c|c|}
\hline \multirow{2}{*}{ HIGH SCHOOL } & \multicolumn{2}{|c|}{ BASE LINE } & \multicolumn{2}{c|}{ FOLLOW-UP } \\
\cline { 2 - 5 } & No. & $\%$ & No. & $\%$ \\
\hline ATTEND & 10 & $15 \%$ & 44 & $40 \%$ \\
\hline DO NOT ATTEND \\
(elementary school completed)
\end{tabular}


School attendance barely changed during the 18 month follow-up period, except for a small increase in high school enrollment. Moreover, elementary school attendance did not vary at all. The numbers were stable enough to indicate a natural flow of USWs from elementary to high school; however, precise numbers are elusive because there was not enough data, and also because of some mis-classification when the children first entered the Program. An example of this situation can be seen in Table 4; by the end of the measurement period, 33 fewer USWs attended elementary school, 34 more attended high school, 10 fewer were not attending elementary school and 9 more were not attending high school. These numbers suggest a spontaneous flow from elementary to high school, yet there is no way to tell precisely the individual movements of the USWs. This almost invariable distribution during the follow-up period contrasts with the high drop out level reported for this population in general (Presidencia, 1992a). The lack of change, though the follow-up period is short, shows that most of the children have remained at school during this interval, despite the rapidly deteriorating conditions in which USWs live (UNICEF/DYA, 1992).

When analyzing the data by levels of education some interesting things appeared: the rate of elementary school attendance (75\%) did not change in the two evaluations. What varied was the children's high school attendance, which increased; at the base line, $15 \%$ were going to high school while $85 \%$ 
were not; at the third follow-up, $40 \%$ were attending and $60 \%$ were not. All in all, the findings point to a modest increase in school enrollment suggested by the maintenance of elementary school attendance in both evaluations, and an increase in high school enrollment. Moreover, compared to other studies on USWs, this sample was doing somewhat better in school attendance.

Regardless of this increase, the attendance rates both in the elementary and higher level were below the national ones that show $96 \%$ of children enrolled in elementary school and $64 \%$ in high school (Presidencia, 1992d). Additionally, the sample had a considerable overall rate of school non attendance $(35 \%)$, which also points to the disadvantaged educational position of this population of USWs.

\section{School Attendance by Age}

The studies done by Garcia and Hernandez (1992) and Cuvi et al. (1989) show that underage workers have fewer years of schooling than they should if age is taken into account, and that school enrollment tends to decrease as age increases. Accordingly, the findings from this research showed that school attendance dropped considerably for the 12 to 17 year old USWs.

When age was correlated with school attendance, the relationship was found to be significant (base line: $p<.00000$; evaluation 3: $p<.00000$ ). One noticeable characteristic of the sample was that a majority of the USWs from 
5 to 11 years old attended school. This high rate of school attendance

contrasted sharply with the poor level of attendance of the older USWs. In the following paragraphs a more detailed description of school attendance by age is presented.

Age group 5 to 11 . At the starting point of this study, three quarters $(77 \%)$ of the subjects in this age category attended school (see Table 7). All of them (except for $1 \%{ }^{28}$ who had already completed it) attended the elementary level. This age category showed high levels of school attendance throughout the study; by the end of the follow-up period, the attendance rate had increased slightly to $81 \%$. But, of course, a fifth of them were not going to school.

Age group 12 to 17 . The educational situation of USWs from 12 to 17 years old was different from that of the younger group: at the base line, $41 \%$ of the group had completed the elementary level but only $5 \%$ attended high school (see Table 7). A considerable percentage of this age group (35\%) were attending elementary school.

It was in this age category where the USWs' educational delay could

\footnotetext{
${ }^{28}$ The usual elementary level completion age is 12 years. However, according to the data drawn from Programa Trabajadores Prematuros' records, there were 13 sample subjects younger than 12 who had already completed the level ( 3 of them were 10 years old and the rest of them were 11). This early completion age was probably related to a miscalculation of their age. Sometimes the USWs who participate in the Program have no identity documents, and neither they nor their parents know their age. Consequently, the Program has to make a guess about it both for its records and in order to obtain an identity card for them at the Records Bureau.
} 
be clearly seen; nearly two thirds $(59 \%)$ of the subjects were not attending any school at the base line. By the end of the follow-up period, the overall percentage of non attendance had increased to $66 \%$ and so, only a third of

TABLE 7.

SCHOOL ATTENDANCE BY AGE

\begin{tabular}{|c|c|c|c|c|c|c|c|c|}
\hline \multirow{3}{*}{$\begin{array}{l}\text { SCHOOL } \\
\text { ATTENDANCE }\end{array}$} & \multicolumn{4}{|c|}{5 to 11} & \multicolumn{4}{|c|}{12 to 17} \\
\hline & \multicolumn{2}{|c|}{ BASE LINE } & \multicolumn{2}{|c|}{ FOLLOW-UP } & \multicolumn{2}{|c|}{ BASE LINE } & \multicolumn{2}{|c|}{ FOLLOW-UP } \\
\hline & No. & $\%$ & No. & $\%$ & No. & $\%$ & No. & $\%$ \\
\hline $\begin{array}{l}\text { ATTEND ELEMENT ARY } \\
\text { SCHOOL }\end{array}$ & 214 & $76 \%$ & 202 & $72 \%$ & 47 & $35 \%$ & 26 & $20 \%$ \\
\hline 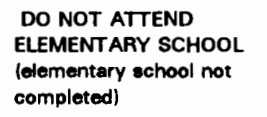 & 54 & $19 \%$ & 41 & $15 \%$ & 31 & $23 \%$ & 34 & $26 \%$ \\
\hline ATTEND HIGH SCHOOL & 3 & $1 \%$ & 24 & $9 \%$ & 7 & $5 \%$ & 20 & $15 \%$ \\
\hline 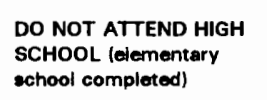 & 9 & $3 \%$ & 13 & $5 \%$ & 48 & $36 \%$ & 53 & $40 \%$ \\
\hline TOTAL & 280 & $100 \%$ & 280 & $100 \%$ & 133 & $100 \%$ & 133 & $100 \%$ \\
\hline
\end{tabular}

them were in school. High school attendance was very low; although it did increase by the end of the follow-up period, only $15 \%$ of the subjects were then enrolled in high school. Comparing the high school attendance rate of the 12 and older USWs to the national one (64\%) (Presidencia, 1992d), the 
USWs rate (15\%) was less than a quarter of the national rate.

When breaking the 12 to 17 year old group into smaller categories (12$13,14-15$ and 16-17), the following things were observed: At the base line, $46 \%$ of the 12-13 year old USWs were going to school, and almost all of them were attending elementary school (see Table 8). High school attendance was very low $(2 \%)$, although slightly over a third of the USWs had already completed the elementary level. By the end of the measurement period, high school attendance of the $12-13$ USWs increased to $16 \%$; however, overall school attendance decreased from $46 \%$ to $34 \%$ and, of course, non attendance increased. At this time, only $57 \%$ of this age group had completed the elementary level in spite of the fact, that according to their age, all the group should have already completed it.

For the 14-15 year old USWs, school attendance at the beginning of the study, was lower than for the $12-13$ year olds; $34 \%$ attended school and only $10 \%$ of them were going to high school, although $53 \%$ had completed the elementary level. USWs non attendance reached $67 \%$ for this group. School attendance of the 14-15 USWs barely changed during the 18 month follow-up, just a slight increase from $34 \%$ to $38 \%$ in school attendance.

The oldest group of USWs (16-17 years old) exhibited very low school attendance although it increased somewhat during the study; $14 \%$ at the base line, and $28 \%$ at the most recent follow-up. At the beginning of the 
TABLE 8.

SCHOOL ATTENDANCE OF USWS 12 AND OLDER

\begin{tabular}{|c|c|c|c|c|c|c|c|c|c|c|c|c|}
\hline \multirow[t]{3}{*}{$\begin{array}{l}\text { SCHOOL } \\
\text { ATTENDANCE }\end{array}$} & \multicolumn{4}{|c|}{$12-13$} & \multicolumn{4}{|c|}{$14-15$} & \multicolumn{4}{|c|}{$16-17$} \\
\hline & \multicolumn{2}{|c|}{ BASE LINE } & \multicolumn{2}{|c|}{$\begin{array}{l}\text { FOLLOW- } \\
\text { UP }\end{array}$} & \multicolumn{2}{|c|}{ BASE LINE } & \multicolumn{2}{|c|}{$\begin{array}{l}\text { FOLLOW- } \\
\text { UP }\end{array}$} & \multicolumn{2}{|c|}{ BASE LINE } & \multicolumn{2}{|c|}{$\begin{array}{l}\text { FOLLOW- } \\
\text { UP }\end{array}$} \\
\hline & No. & $\%$ & No. & $\%$ & No. & $\%$ & No. & $\%$ & No. & $\%$ & No. & $\%$ \\
\hline $\begin{array}{l}\text { ATTEND ELEMENTARY } \\
\text { SCHOOL }\end{array}$ & 37 & $44 \%$ & 15 & $18 \%$ & 10 & $24 \%$ & 10 & $24 \%$ & 0 & $0 \%$ & 1 & $14 \%$ \\
\hline $\begin{array}{l}\text { DO NOT ATTEND ELEMENTARY } \\
\text { SCHOOL (elementary school not } \\
\text { completed) }\end{array}$ & 16 & $19 \%$ & 22 & $26 \%$ & 10 & $24 \%$ & 9 & $21 \%$ & 5 & $71 \%$ & 3 & $43 \%$ \\
\hline ATTEND HIGH SCHOOL & 2 & $2 \%$ & 13 & $16 \%$ & 4 & $10 \%$ & 6 & $14 \%$ & 1 & $14 \%$ & 1 & $14 \%$ \\
\hline $\begin{array}{l}\text { DO NOT ATTEND HIGH } \\
\text { SCHOOL (elementary school } \\
\text { completed) }\end{array}$ & 29 & $35 \%$ & 34 & $41 \%$ & 18 & $43 \%$ & 17 & $41 \%$ & 1 & $14 \%$ & 2 & $29 \%$ \\
\hline TOTAL & 84 & $100 \%$ & 84 & $100 \%$ & 42 & $100 \%$ & 42 & $100 \%$ & 7 & $100 \%$ & 7 & $100 \%$ \\
\hline
\end{tabular}


measurement period, only $28 \%$ had completed elementary school, whereas, at the end of it, $43 \%$ had completed the level. All but one of the USWs in this age category who attended school, were going to high school at the last follow-up.

When comparing the three groups, it was observed that school attendance decreased for the 12-13 USWs, barely changed for the 14-15 year olds and increased for the 16-17 USWs. Additionally, the data showed that elementary school completion decreased as age increased: $57 \%$ of the first group, $55 \%$ of the intermediate one and $43 \%$ of the older one, had completed the level. High school attendance of the USWs at the base line showed a trend towards higher rates as age increased, that is, the older groups exhibited higher high school attendance rates than the younger ones. However, by the end of the measurement period, only the high school attendance of the 12-13 USWs showed a relative increase, the 14-15 USW' barely increased and the 16-17 USWs' did not change.

Differences between age categories. A sharp difference between the school attendance rate of the two age groups was observed. By the end of the follow-up period, the school attendance rate of the younger group was more than double that of the older group. UNICEF and OIT (1994), in their analysis of child work in Ecuador, drawing on census data to compare school attendance of children 10 to 17 years old who participate in the labor market 
and those who do not, depict the educational disadvantage of the working children: $50 \%$ of the underage workers go to school compared to $97 \%$ of the non working children. The non-attendance rate $(50 \%)$ found by UNICEF and OIT (1994) is somewhat similar to the one found in this study at the first evaluation, for the age group 12 to $17(59 \%)$. This suggests that the higher overall rate of school attendance found in this study may be due to the larger number of children under going to school who were not taken into account in the previously mentioned study. The data from this study also pointed out that school attendance was higher for the younger group than the older one.

\section{School Attendance by Location}

Novillo (1994), in her study on the situation of the families of USWs who participate in Programa Trabajadores Prematuros in several Ecuadorian towns, describes, by location, the main economic activities of USWs and their parents, plus the educational levels of the latter, and points out the relationships among them.

Regarding educational levels, Novillo (1994) found that USWs' parents in Cuenca were the better educated. Parents in Otavalo occupied the second place and parents from Ambato came in third, yet the differences between the last two were small. These findings are very compatible with what the present study showed about the USWs' school attendance by location. A clear 
difference was observed between the number of children going to school in Cuenca and the other two cities, Ambato and Otavalo, which behave rather similarly.

The data showed a significant relationship between school attendance and location (base line: $p<.00001$; the end of the measurement period: $p<$ .00000). In the following paragraphs, the USWs' school attendance by location and the differences among them will be examined.

Otavalo. At the beginning of the measurement period, $15 \%$ of Otavalo USWs had completed the elementary level. School attendance is low in this small town; slightly over half ( $54 \%$ ) of the USWs were going to school at the first evaluation; all of them attended the elementary level (see Table 9).

Observable differences between the base line and third follow-up are a minimal increase in high school attendance, and the larger number of children $(20 \%)$ with an elementary certificate. School attendance is poor in both evaluation periods, particularly high school attendance; only two children in this location were attending high school by the end of the follow-up period.

Ambato. The school attendance rate of Ambato USWs is slightly higher than that of Otavalo; at the first evaluation, $59 \%$ of this group were going to school. Most of them attended elementary school; $23 \%$ of the children in this location had completed elementary school. 
By the end of the follow up period, $40 \%$ of the USWs had completed the elementary level. Consequently, high school attendance increased to $16 \%$, while elementary school attendance declined to $39 \%$. In spite of the small increase in high school enrollment, the overall percentage of children not going to school increased slightly (45\%).

Notable variations between the base line and follow-up periods are an increase in high school attendance, and a decrease in elementary school attendance.

Cuenca. This location has an outstanding number of USWs attending school; at the beginning of the follow-up period $83 \%$ of the subjects there were going to school. Most of them attended elementary school. Completion of elementary school was $4 \%$ for this site and is related to the young age of the sample.

At the third evaluation, school attendance increased to $91 \%$; both the primary and high school levels exhibited higher percentages of children going to school, and non attendance decreased proportionately. USWs with an elementary level completed doubled to $8 \%$ by the follow-up period.

Cuenca's salient feature during the 18 month follow-up was the large number of children attending school (this sample's attendance rate was closest to the national one [96\%] [Presidencia, 1992]). The bulk of this group is concentrated in the elementary level, due to the young age of the 
TABLE 9.

SCHOOL ATTENDANCE BY LOCATION

\begin{tabular}{|c|c|c|c|c|c|c|c|c|c|c|c|c|}
\hline \multirow[t]{3}{*}{$\begin{array}{l}\text { SCHOOL } \\
\text { ATTENDANCE }\end{array}$} & \multicolumn{4}{|c|}{ OTAVALO } & \multicolumn{4}{|c|}{ AMBATO } & \multicolumn{4}{|c|}{ CUENCA } \\
\hline & \multicolumn{2}{|c|}{ BASE LINE } & \multicolumn{2}{|c|}{$\begin{array}{l}\text { FOLLOW- } \\
\text { UP }\end{array}$} & \multicolumn{2}{|c|}{ BASE LINE } & \multicolumn{2}{|c|}{$\begin{array}{l}\text { FOLLOW- } \\
\text { UP }\end{array}$} & \multicolumn{2}{|c|}{ BASE LINE } & \multicolumn{2}{|c|}{$\begin{array}{l}\text { FOLLOW- } \\
\text { UP }\end{array}$} \\
\hline & No. & $\%$ & No. & $\%$ & No. & $\%$ & No. & $\%$ & No. & $\%$ & No. & $\%$ \\
\hline $\begin{array}{l}\text { ATTEND ELEMENTARY } \\
\text { SCHOOL }\end{array}$ & 35 & $54 \%$ & 35 & $54 \%$ & 125 & $56 \%$ & 87 & $39 \%$ & 101 & $81 \%$ & 106 & $85 \%$ \\
\hline $\begin{array}{l}\text { DO NOT ATTEND ELEMENT ARY } \\
\text { SCHOOL (elementary school not } \\
\text { completed) }\end{array}$ & 20 & $31 \%$ & 17 & $26 \%$ & 46 & $21 \%$ & 48 & $21 \%$ & 19 & $15 \%$ & 10 & $8 \%$ \\
\hline ATTEND HIGH SCHOOL & 0 & $0 \%$ & 2 & $3 \%$ & 8 & $3 \%$ & 35 & $16 \%$ & 2 & $2 \%$ & 7 & $6 \%$ \\
\hline $\begin{array}{l}\text { DO NOT ATTEND HIGH } \\
\text { SCHOOL (elementary school } \\
\text { completed) }\end{array}$ & 10 & $15 \%$ & 11 & $17 \%$ & 44 & $20 \%$ & 53 & $24 \%$ & 3 & $2 \%$ & 2 & $2 \%$ \\
\hline TOTAL & 65 & $100 \%$ & 65 & $100 \%$ & 223 & $100 \%$ & 223 & $100 \%$ & 125 & $100 \%$ & 125 & $100 \%$ \\
\hline
\end{tabular}


subjects. High school attendance is also notable; 7 of the 9 children with an elementary degree attended high school. Accordingly, school non attendance in this site comprises the lowest percentage of the three sample locations.

Differences among locations. Comparing school attendance of the three locations the following elements can be noticed: (1)School attendance was, by far, higher in Cuenca at the beginning and end of the 18 month follow-up period; (2)the USWs in Ambato and Otavalo had a similar school attendance rate; at the first evaluation Ambato USWs' rate was slightly higher whereas in the most recent follow-up Otavalo USWs' rate was higher. School attendance at Otavalo and Ambato is lower than the entire sample's average at the 18 month follow-up time. This means that if Cuenca's sample were excluded, the percentage of the USWs attending school would drop to $56 \%$; (3)during the follow-up period, Cuenca USWs showed greater improvement in school attendance than the other two locations. Otavalo USWs follow with a modest increase, and Ambato USWs increased somewhat in terms of high school but its overall attendance rate decreased. (4)in the case of Cuenca and Otavalo, both of which had younger subjects, almost the entire sample was in the elementary level. Ambato, which had the oldest population of the three locations, shows a more balanced attendance distribution in the two levels.

The USWs in Cuenca show a different situation: a considerable higher 
percentage of them are attending school. Further research is needed to account for the difference found in Cuenca. However, it may be speculated that the population of this location places a higher value on education than the other cities. This situation is reflected in the educational behavior of the USWs and their parents, because: (1)Traditionally this location is renowned in the country as being an educated city to the point that it is referred to as the "Athens of Ecuador", (2)census data (INEC, 1991C) show the main economic activities of this city to be professional or semi-professional activities, both of which require higher levels of education.

\section{School Attendance by Gender}

The literature points to the disadvantaged educational situation of women in Latin America despite recent efforts to facilitate their access to educational services (Acosta, 1989; Elhers, 1990; Stromquist, 1989; Population Reference Bureau, 1986). In Ecuador, census data show no differences in enrollment rates between girls and boys, but still $60 \%$ of the illiterate people are female (Presidencia, 1992d). The situation of underage female workers, according to Garcia and Hernandez (1992), is even more disadvantaged. They found that only $33.3 \%$ of them attended school. Additionally, Novillo (1994) in her study of the USWs' family situation established that the USWs' mothers have less schooling than their fathers.

The findings from this study show a different scenario; the hypothesis 
that the rate of school attendance would be lower for the female USWs than for the males was not supported; in fact, more female USWs than male USWs went to elementary during the 18 months the sample was followed. However at the high school level, there were actually no differences between genders. The relationship between gender and school attendance was found to be significant (at $p<.05$ level) both at the beginning and end of the study (base line: $p<.00028$; evaluation 3: $p<.02323)$.

In the following paragraphs, a description of school attendance of the male and female USWs will be presented by comparing the base line data with those in the most recent evaluation, followed by an analysis of the differences between the two groups.

Female USWs. At the beginning of the measurement period, $10 \%$ of the female USWs had completed the elementary level while $90 \%$ of them had not. The bulk of the female group (77\%) were going to school; most of them (74\%) attended elementary school and few of them (3\%) went to high school. Almost a quarter (23\%) of the girls were not attending school; $16 \%$ had not completed elementary school and were not attending this level, and $7 \%$ had completed elementary school and were not going to high school (see Table 10).

By the end of the measurement period, the percentage of girls with an elementary degree had doubled to $20 \%$. School attendance for the girls had 
decreased somewhat, from $77 \%$ to $73 \% ; 10 \%$ of them were going to high school and $63 \%$ attended elementary school.

A few differences were observed between the two evaluations; one was the doubled number of girls who completed elementary school; another one was a slight decline in elementary school attendance. Finally, some increase in high school enrollment could be seen. At both times, the majority of the girls attended elementary school.

TABLE 10.

SCHOOL ATTENDANCE BY GENDER

\begin{tabular}{|c|c|c|c|c|c|c|c|c|}
\hline \multirow{3}{*}{$\begin{array}{l}\text { SCHOOL } \\
\text { ATTENDANCE }\end{array}$} & \multicolumn{4}{|c|}{ MALES } & \multicolumn{4}{|c|}{ FEMALES } \\
\hline & \multicolumn{2}{|c|}{ BASE LINE } & \multicolumn{2}{|c|}{ FOLLOW-UP } & \multicolumn{2}{|c|}{ BASE LINE } & \multicolumn{2}{|c|}{ FOLLOW-UP } \\
\hline & No. & $\%$ & No. & $\%$ & No. & $\%$ & No. & $\%$ \\
\hline $\begin{array}{l}\text { ATTEND ELEMENTARY } \\
\text { SCHOOL }\end{array}$ & 147 & $57 \%$ & 131 & $51 \%$ & 114 & $74 \%$ & 97 & $63 \%$ \\
\hline $\begin{array}{l}\text { DO NOT ATTEND } \\
\text { ELEMENATARY SCHOOL } \\
\text { (elementary school not } \\
\text { completedod) }\end{array}$ & 60 & $23 \%$ & 49 & $19 \%$ & 25 & $16 \%$ & 26 & $17 \%$ \\
\hline ATTEND HIGH SCHOOL & 6 & $2 \%$ & 29 & $11 \%$ & 4 & $3 \%$ & 15 & $10 \%$ \\
\hline 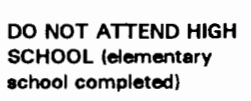 & 46 & $18 \%$ & 50 & $19 \%$ & 11 & $7 \%$ & 16 & $10 \%$ \\
\hline TOTAL & 259 & $100 \%$ & 259 & 100 & 154 & $100 \%$ & 154 & $100 \%$ \\
\hline
\end{tabular}

When the girl's school attendance was correlated with age, the 
relationship was found significant (base line: $p<00000$; evaluation 3: $p<$ 00000). The school attendance of the female USWs showed the following:

For the 5 to 11 year old girls, elementary school attendance decreased from $84 \%$ to $76 \%$, but high school attendance increased some (see Table 11).

School non attendance barely changed during the study. Additionally, the percentage of female USWs who completed the elementary school increased from $5 \%$ to $13 \%$ during the measurement period. Thus, the distribution showed a possible flow of the girls from elementary to high school. For the 12 to 17 group, the overall school attendance decreased during the 18 month follow-up from $43 \%$ to $29 \%$; elementary school attendance decreased from $40 \%$ to $20 \%$, but high school attendance increased $3 \%$ to $9 \%$. School non attendance both to elementary and high school increased.

Completion of elementary school increased from $29 \%$ to $43 \%$. One interpretation of these distribution is that some of the girls who were attending elementary school at the base line continued to high school while others dropped from school.

When breaking the 12 to 17 year old group into three categories (12$13,14-15$ and 16-17) it was observed that elementary school attendance of the $12-13$ girls decreased from $45 \%$ to $5 \%$ and non attendance increased from $50 \%$ to $80 \%$ by the end of the measurement period (see Table 12). High school attendance and completion of elementary school exhibited small 
TABLE 11.

FEMALE USWs SCHOOL ATTENDANCE BY AGE

\begin{tabular}{|c|c|c|c|c|c|c|c|c|}
\hline \multirow{3}{*}{$\begin{array}{l}\text { SCHOOL } \\
\text { ATTENDANCE }\end{array}$} & \multicolumn{4}{|c|}{5 to 11} & \multicolumn{4}{|c|}{12 to 17} \\
\hline & \multicolumn{2}{|c|}{ BASE LINE } & \multicolumn{2}{|c|}{ FOLLOW-UP } & \multicolumn{2}{|c|}{ BASE LINE } & \multicolumn{2}{|c|}{ FOLLOW-UP } \\
\hline & No. & $\%$ & No. & $\%$ & No. & $\%$ & No. & $\%$ \\
\hline $\begin{array}{l}\text { ATTEND ELEMENTARY } \\
\text { SCHOOL }\end{array}$ & 100 & $84 \%$ & 90 & $76 \%$ & 14 & $40 \%$ & 7 & $20 \%$ \\
\hline $\begin{array}{l}\text { DO NOT ATTEND } \\
\text { ELEMENARY SCHOOL } \\
\text { (elementary school not } \\
\text { completed) }\end{array}$ & 14 & $12 \%$ & 13 & $11 \%$ & 11 & $31 \%$ & 13 & $37 \%$ \\
\hline ATTEND HIGH SCHOOL & 3 & $3 \%$ & 12 & $10 \%$ & 1 & $3 \%$ & 3 & $9 \%$ \\
\hline $\begin{array}{l}\text { DO NOT ATTEND HIGH } \\
\text { ScHOOL (olementrary } \\
\text { school completeded) }\end{array}$ & 2 & $2 \%$ & 4 & $3 \%$ & 9 & $26 \%$ & 12 & $34 \%$ \\
\hline TOTAL & 119 & $100 \%$ & 119 & $100 \%$ & 35 & $100 \%$ & 35 & $100 \%$ \\
\hline
\end{tabular}

increases. This group showed the highest percentage of elementary school completion, and a notable drop in elementary school attendance. A salient feature of the 14-15 female USWs was that none of them were attending high school at the follow-up. Additionally, a small increase in elementary school attendance from $38 \%$ to $46 \%$ was observed. The two girls in the $16-17$ year old group had not completed the elementary level and were not attending school during the study.

Recapitulating, a larger number of the younger girls than the older 
TABLE 12.

SCHOOL ATTENDANCE OF FEMALE USWS OLDER THAN 12

\begin{tabular}{|c|c|c|c|c|c|c|c|c|c|c|c|c|}
\hline \multirow{3}{*}{$\begin{array}{l}\text { SCHOOL } \\
\text { ATTENDANCE }\end{array}$} & \multicolumn{4}{|c|}{$12-13$} & \multicolumn{4}{|c|}{$14-15$} & \multicolumn{4}{|c|}{$16-17$} \\
\hline & \multicolumn{2}{|c|}{ BASE LINE } & \multicolumn{2}{|c|}{$\begin{array}{l}\text { FOLLOW- } \\
\text { UP }\end{array}$} & \multicolumn{2}{|c|}{ BASE LINE } & \multicolumn{2}{|c|}{$\begin{array}{l}\text { FOLLOW- } \\
\text { UP }\end{array}$} & \multicolumn{2}{|c|}{ BASE LINE } & \multicolumn{2}{|c|}{$\begin{array}{l}\text { FOLLOW- } \\
\text { UP }\end{array}$} \\
\hline & No. & $\%$ & No. & $\%$ & No. & $\%$ & No. & $\%$ & No. & $\%$ & No. & $\%$ \\
\hline $\begin{array}{l}\text { ATTEND ELEMENTARY } \\
\text { SCHOOL }\end{array}$ & 9 & $45 \%$ & 1 & $5 \%$ & 5 & $38 \%$ & 6 & $46 \%$ & 0 & $0 \%$ & 0 & $0 \%$ \\
\hline $\begin{array}{l}\text { DO NOT ATTEND ELEMENTARY } \\
\text { SCHOOL (elementary school not } \\
\text { completed) }\end{array}$ & 4 & $20 \%$ & 7 & $35 \%$ & 5 & $38 \%$ & 4 & $31 \%$ & 2 & $100 \%$ & 2 & $100 \%$ \\
\hline ATTEND HIGH SCHOOL & 1 & $5 \%$ & 3 & $15 \%$ & 0 & $0 \%$ & 0 & $0 \%$ & 0 & $0 \%$ & 0 & $0 \%$ \\
\hline $\begin{array}{l}\text { DO NOT ATTEND HIGH } \\
\text { SCHOOL (elementary school } \\
\text { completed) }\end{array}$ & 6 & $30 \%$ & 9 & $45 \%$ & 3 & $23 \%$ & 3 & $23 \%$ & 0 & $0 \%$ & 0 & $0 \%$ \\
\hline TOTAL & 20 & $100 \%$ & 20 & $100 \%$ & 13 & $100 \%$ & 13 & $100 \%$ & 2 & $100 \%$ & 2 & $100 \%$ \\
\hline
\end{tabular}


ones attended school. Non attendance rates were stable during the 18 months for the 5 to 11 group and increased for the older group. High school attendance rates were strikingly similar for both groups, when higher rates were expected for the 12 to 17 group.

When looking at female school attendance by location, the correlation between these variables was found significant (base line: $p<00006$; evaluation 3: $p<00010$ ). The overall school attendance of the girls in Otavalo exhibited no changes, Ambato's decreased and Cuenca's improved slightly; $44 \%$ of the girls in Otavalo were attending elementary school during the study and the rest of the group was not attending school (see Table 13). In Ambato, the girls' school attendance decreased from $81 \%$ to $50 \%$ during the measurement period, high school attendance increased from $5 \%$ to $19 \%$, but non attendance at both levels increased. In Cuenca, the girls' elementary school attendance barely changed during the follow-up (base line: $80 \%$; evaluation 3: $81 \%$ ), high school attendance increased from $1 \%$ to $6 \%$ and non attendance decreased from $19 \%$ to $13 \%$.

Girls in Cuenca and Ambato exhibited similar elementary school attendance rate; however, the latter dropped notably by the end of the followup period. Otavalo girls showed the lowest school attendance rates of the three locations.

Male USWs. One fifth (20\%) of the male USWs had completed 
TABLE 13.

SCHOOL ATTENDANCE OF FEMALE USWS BY LOCATION

\begin{tabular}{|c|c|c|c|c|c|c|c|c|c|c|c|c|}
\hline \multirow{3}{*}{$\begin{array}{l}\text { SCHOOL } \\
\text { ATTENDANCE }\end{array}$} & \multicolumn{4}{|c|}{ OTAVALO } & \multicolumn{4}{|c|}{ AMBATO } & \multicolumn{4}{|c|}{ CUENCA } \\
\hline & \multicolumn{2}{|c|}{ BASE LINE } & \multicolumn{2}{|c|}{$\begin{array}{l}\text { FOLLOW- } \\
\text { UP }\end{array}$} & \multicolumn{2}{|c|}{ BASE LINE } & \multicolumn{2}{|c|}{$\begin{array}{l}\text { FOLLOW- } \\
\text { UP }\end{array}$} & \multicolumn{2}{|c|}{ BASE LINE } & \multicolumn{2}{|c|}{$\begin{array}{l}\text { FOLLOW- } \\
\text { UP }\end{array}$} \\
\hline & No. & $\%$ & No. & $\%$ & No. & $\%$ & No. & $\%$ & No. & $\%$ & No. & $\%$ \\
\hline $\begin{array}{l}\text { ATTEND ELEMENTARY } \\
\text { SCHOOL }\end{array}$ & 12 & $44 \%$ & 12 & $44 \%$ & 47 & $81 \%$ & 29 & $50 \%$ & 55 & $80 \%$ & 56 & $81 \%$ \\
\hline $\begin{array}{l}\text { DO NOT ATTEND ELEMENTARY } \\
\text { SCHOOL (elementary school not } \\
\text { completed) }\end{array}$ & 10 & $37 \%$ & 8 & $30 \%$ & 4 & $7 \%$ & 10 & $17 \%$ & 11 & $16 \%$ & 8 & $12 \%$ \\
\hline ATTEND HIGH SCHOOL & 0 & $0 \%$ & 0 & $0 \%$ & 3 & $5 \%$ & 11 & $19 \%$ & 1 & $1 \%$ & 4 & $6 \%$ \\
\hline $\begin{array}{l}\text { DO NOT ATTEND HIGH } \\
\text { SCHOOL (elementary school } \\
\text { completed) }\end{array}$ & 5 & $19 \%$ & 7 & $26 \%$ & 4 & $7 \%$ & 8 & $14 \%$ & 2 & $3 \%$ & 1 & $1 \%$ \\
\hline TOTAL & 27 & $100 \%$ & 27 & $100 \%$ & 58 & $100 \%$ & 58 & $100 \%$ & 69 & $100 \%$ & 69 & $100 \%$ \\
\hline
\end{tabular}


elementary school at the beginning of the study. More than half $(59 \%)$ of the boys were going to school: almost all of them attended elementary school.

Two fifths (41\%) of the male USWs were not enrolled in school; $23 \%$ who had not completed elementary school were not attending this level, and $18 \%$ with elementary school completed were not going to high school (see Table 10).

By the third evaluation, the percentage of boys who had completed elementary school had increased by $50 \%$. School attendance overall was very similar to the first evaluation (62\%) but its distribution in the two levels varied; $51 \%$ were going to elementary school and $11 \%$ to high school. School

\section{TABLE 14}

MALE USWS SCHOOL ATTENDANCE BY AGE

\begin{tabular}{|c|c|c|c|c|c|c|c|c|}
\hline \multirow{3}{*}{$\begin{array}{l}\text { SCHOOL } \\
\text { ATTENDANCE }\end{array}$} & \multicolumn{4}{|c|}{5 to 11} & \multicolumn{4}{|c|}{12 to 17} \\
\hline & \multicolumn{2}{|c|}{ BASE LINE } & \multicolumn{2}{|c|}{ FOLLOW-UP } & \multicolumn{2}{|c|}{ BASE LINE } & \multicolumn{2}{|c|}{ FOLLOW-UP } \\
\hline & No. & $\%$ & No. & $\%$ & No. & $\%$ & No. & $\%$ \\
\hline $\begin{array}{l}\text { ATTEND ELEMENTARY } \\
\text { SCHOOL }\end{array}$ & 114 & $71 \%$ & 112 & $70 \%$ & 33 & $34 \%$ & 19 & $19 \%$ \\
\hline $\begin{array}{l}\text { DO NOT ATTEND } \\
\text { ELEMENTARY SCHOOL } \\
\text { (elementeryy school not } \\
\text { completeded) }\end{array}$ & 40 & $25 \%$ & 28 & $17 \%$ & 20 & $20 \%$ & 21 & $21 \%$ \\
\hline ATTEND HIGH SCHOOL & 0 & $0 \%$ & 12 & $7 \%$ & 6 & $6 \%$ & 17 & $17 \%$ \\
\hline $\begin{array}{l}\text { DO NOT ATTEND HIGH } \\
\text { SCCOOL (elementary } \\
\text { school comploteted) }\end{array}$ & 7 & $4 \%$ & 9 & $6 \%$ & 39 & $40 \%$ & 41 & $42 \%$ \\
\hline TOTAL & 161 & $100 \%$ & 161 & $100 \%$ & 98 & $100 \%$ & 98 & $100 \%$ \\
\hline
\end{tabular}


non attendance dropped slightly from $41 \%$ to $38 \%$ due to the drop in elementary school attendance.

In both evaluations, boys followed the same pattern as the girls: (1)the majority of the boys attended elementary school; and, (2)some increase in high school attendance was observed.

When male school attendance was correlated with age, the relationship was found significant (base line and evaluation 3: $p<00000$ ). For the 5 to 11 boys, elementary school attendance barely changed (base line: $71 \%$, evaluation 3: $70 \%$ ) and high school attendance increased from $0 \%$ to $7 \%$. Non attendance increased from $25 \%$ to $7 \%$ and high school non attendance increased minimally. Completion of elementary school also increased from $4 \%$ to $13 \%$. The 12 to 17 year old boys exhibited a decrease from $34 \%$ to $19 \%$ in elementary school attendance, an increase from $6 \%$ to $17 \%$ in high school attendance, and an increase in elementary school completion rates from $46 \%$ to $59 \%$. Non attendance rates barely changed (see Table 14).

When looking at the older group broken into smaller categories (12-13, $14-15,16-17)$ the following were observed: Elementary school attendance of the $12-13$ year old decreased from $44 \%$ to $22 \%$, whereas high school attendance rates were stable during the 18 month follow-up. Completion of elementary school increased from $38 \%$ to $55 \%$. The $14-15$ year old boys 
TABLE 15.

SCHOOL ATTENDANCE OF MALE USWS OLDER THAN 12

\begin{tabular}{|c|c|c|c|c|c|c|c|c|c|c|c|c|}
\hline \multirow{3}{*}{$\begin{array}{l}\text { SCHOOL } \\
\text { ATTENDANCE }\end{array}$} & \multicolumn{4}{|c|}{$12-13$} & \multicolumn{4}{|c|}{$14-15$} & \multicolumn{4}{|c|}{$16-17$} \\
\hline & \multicolumn{2}{|c|}{ BASE LINE } & \multicolumn{2}{|c|}{$\begin{array}{l}\text { FOLLOW- } \\
\text { UP }\end{array}$} & \multicolumn{2}{|c|}{ BASE LINE } & \multicolumn{2}{|c|}{$\begin{array}{l}\text { FOLLOW- } \\
\text { UP }\end{array}$} & \multicolumn{2}{|c|}{ BASE LINE } & \multicolumn{2}{|c|}{$\begin{array}{l}\text { FOLLOW- } \\
\text { UP }\end{array}$} \\
\hline & No. & $\%$ & No. & $\%$ & No. & $\%$ & No. & $\%$ & No. & $\%$ & No. & $\%$ \\
\hline $\begin{array}{l}\text { ATTEND ELEMENTARY } \\
\text { SCHOOL }\end{array}$ & 28 & $44 \%$ & 14 & $22 \%$ & 5 & $17 \%$ & 4 & $14 \%$ & 0 & $0 \%$ & 1 & $20 \%$ \\
\hline $\begin{array}{l}\text { DO NOT ATTEND ELEMENTARY ARY } \\
\text { sCHOOL (delementary sechool not } \\
\text { completed) }\end{array}$ & 12 & $19 \%$ & 15 & $23 \%$ & 5 & $17 \%$ & 5 & $17 \%$ & 3 & $60 \%$ & 1 & $20 \%$ \\
\hline ATTEND HIGH SCHOOL & 1 & $2 \%$ & 10 & $16 \%$ & 4 & $14 \%$ & 6 & $21 \%$ & 1 & $20 \%$ & 1 & $20 \%$ \\
\hline $\begin{array}{l}\text { DO NOT ATTEND HIGH } \\
\text { SCHOOL (deementary school } \\
\text { completed) }\end{array}$ & 23 & $36 \%$ & 25 & $39 \%$ & 15 & $52 \%$ & 14 & $48 \%$ & 1 & $20 \%$ & 2 & $40 \%$ \\
\hline TOTAL & 64 & $100 \%$ & 64 & $100 \%$ & 29 & $100 \%$ & 29 & $100 \%$ & 5 & $100 \%$ & 5 & $100 \%$ \\
\hline
\end{tabular}


showed minimal changes during the measurement period, except for a moderate increase in high school attendance from $14 \%$ to $21 \%$. The $16-17$ year old boys exhibited a non attendance rate of $80 \%$, at the base line, which decreased to $60 \%$ at the follow-up, plus they showed an increase in the overall school attendance rate (from $20 \%$ to $40 \%$ ) and also in elementary school completion rates (from $40 \%$ to $60 \%$ ) (see Table 15 ).

Overall school attendance rates for the three categories of 12-17 year old boys were below $50 \%$. The $12-13$ and $14-15$ year old boys improved their high school attendance rates while the 16-17 USWs improved elementary school attendance rates. The three categories exhibited some decrease in non attendance rates, particularly the oldest group.

Comparing the younger with the older group, school attendance rates were considerably higher for the former; at the base line, the rate nearly doubled that of the older group, and, by the end of the study, the difference became even more pronounced. Both groups improved high school attendance, and the younger group succeeded in decreasing elementary school non attendance rates.

When correlating male school attendance and location the relationship proved to be significant (base line: $p<00006$, evaluation 3: $p<00000$ ). In Otavalo, the boys exhibited a $61 \%$ elementary school attendance rate which did not changed during the follow-up period. Only a small increase in high 
TABLE 16.

SCHOOL ATTENDANCE OF THE MALE USWS BY LOCATION

\begin{tabular}{|c|c|c|c|c|c|c|c|c|c|c|c|c|}
\hline \multirow{3}{*}{$\begin{array}{l}\text { SCHOOL } \\
\text { ATTENDANCE }\end{array}$} & \multicolumn{4}{|c|}{ OTAVALO } & \multicolumn{4}{|c|}{ AMBATO } & \multicolumn{4}{|c|}{ CUENCA } \\
\hline & \multicolumn{2}{|c|}{ BASE LINE } & \multicolumn{2}{|c|}{$\begin{array}{l}\text { FOLLOW- } \\
\text { UP }\end{array}$} & \multicolumn{2}{|c|}{ BASE LINE } & \multicolumn{2}{|c|}{$\begin{array}{l}\text { FOLLOW- } \\
\text { UP }\end{array}$} & \multicolumn{2}{|c|}{ BASE LINE } & \multicolumn{2}{|c|}{$\begin{array}{l}\text { FOLLOW- } \\
\text { UP }\end{array}$} \\
\hline & No. & $\%$ & No. & $\%$ & No. & $\%$ & No. & $\%$ & No. & $\%$ & No. & $\%$ \\
\hline $\begin{array}{l}\text { ATTEND ELEMENTARY } \\
\text { SCHOOL }\end{array}$ & 23 & $61 \%$ & 23 & $61 \%$ & 78 & $47 \%$ & 58 & $35 \%$ & 46 & $82 \%$ & 50 & $89 \%$ \\
\hline $\begin{array}{l}\text { DO NOT ATTEND ELEMENTARY } \\
\text { SCHOOL (elementary school not } \\
\text { completed) }\end{array}$ & 10 & $26 \%$ & 9 & $24 \%$ & 42 & $26 \%$ & 38 & $23 \%$ & 8 & $14 \%$ & 2 & $4 \%$ \\
\hline ATTEND HIGH SCHOOL & 0 & $0 \%$ & 2 & $5 \%$ & 5 & $3 \%$ & 24 & $15 \%$ & 1 & $2 \%$ & 3 & $5 \%$ \\
\hline $\begin{array}{l}\text { DO NOT ATTEND HIGH } \\
\text { SCHOOL (elementary school } \\
\text { completed) }\end{array}$ & 5 & $13 \%$ & 4 & $11 \%$ & 40 & $24 \%$ & 45 & $27 \%$ & 1 & $2 \%$ & 1 & $2 \%$ \\
\hline TOTAL & 38 & $100 \%$ & 38 & $100 \%$ & 165 & $100 \%$ & 165 & $100 \%$ & 56 & $100 \%$ & 56 & $100 \%$ \\
\hline
\end{tabular}


school attendance and elementary school completion were observed in this location. In Ambato, the elementary school attendance decreased from $47 \%$ to $35 \%$, high school attendance increased from $3 \%$ to $15 \%$, and school non attendance rates were stable during the study. Elementary school completion increased from $27 \%$ to $42 \%$. In Cuenca, the boys school attendance rate increased from $84 \%$ to $94 \%$ and elementary school completion rate increased from $4 \%$ to $7 \%$ (the low elementary completion rate is related to the young age of Cuenca's sample) (see Table 16).

Summarizing, it was observed that the elementary school completion rates increased in all three locations; school attendance of Otavalo boys' barely changed; boys in Ambato showed the lowest school attendance rates of the three locations; and, Cuenca boys, by the end of the measurement period, exhibited a male school attendance rate $(94 \%)$ close to the national one $(96 \%$ [INEC, 1991d) .

Differences between male and females USWs. When comparing the USW female group with the male group the following differences were found: (1)The number of girls with the elementary level completed increased more than the number of boys; (2)as already mentioned, more girls than boys attended school, but the differences between the two groups narrowed at the high school level; (3)boys' school attendance improved slightly more than girls. At the most recent follow-up, the data suggested that more boys than 
girls attended high school. In the following paragraphs, the observed differences between boys and girls are explained in greater detail, taking into account the age and location variables.

Observed differences between school attendance of the male and female USWs 5 to 11 years old were the following: The girls exhibited higher rates of elementary and high school attendance than boys. Both genders improved their high school attendance during the study; however, girls' elementary school attendance decreased while the boys maintained the same rate during the study. Additionally, boys' non attendance rates decreased whereas girls' did not change. The overall school attendance rates were higher for the female USWs; however, during the measurement period the data suggested that the boys were making slightly more improvement in school attendance than the girls.

For the 12 to 17 year old group, elementary school attendance rates were higher for girls at the beginning of the study, but, by the end of it, the rates became very close for both genders. Boys and girls both showed improved high school attendance rates, with boys' rates slightly higher than girls' at the last follow-up. Elementary school non attendance rates were higher for the girls than for boys. Additionally, boys were more likely than girls to complete elementary school.

Comparing school attendance of the 12-13 year old boys and girls the 
following things were observed: at the base line, the elementary school attendance rates were very similar for males and females and, during the follow-up, they decreased considerably for both genders but more pronouncedly for the girls. High school attendance rates exhibited similar increases for both genders. The 14-15 year old category showed the following: more girls than boys attended school during the study, and the attendance rates of girls increased while that of the boys decreased. None of the girls in this age category were attending high school while some of the boys did, and the latter's attendance rate increased by the end of the study. The elementary and high school attendance of the 16-17 year olds was higher for the males than for the female.

Differences found in school attendance by location between the USWS boys and girls were the following: In Otavalo, elementary school attendance rates were higher for the boys than for the girls, and the girls' rate (but not the boys') decreased by the follow-up period. Male high school attendance increased, whereas there were no girls attending the level in this location. The elementary completion rates increased for both sexes, more so for the girls than for the boys.

In Ambato, the girls' elementary school attendance rate was higher than the boys', and during the measurement period it decreased for both genders, but more pronouncedly for the girls. High school attendance rates 
were similar for boys and giris and both increased. Elementary completion rates were higher for boys at the base line, however, by the end of the study, the girls increased and surpassed that of boys'.

In Cuenca, the school attendance of boys and girls was found very similar; both elementary and high school attendance rates were similar for both genders, although at the elementary level, they increased more for the male USWs. High school attendance rate was similar for both genders too, girls' increased slightly more than boys' (see Table 15 and 18).

Recapitulating, when correlating the boys' and girls' school attendance with age and location, the observed overall advantage of the female USWs in school attendance rates were found to be relative and rather small; by age groups, more 5 to 11 girls than 5 to 11 boys attended school; however, in the 12 to 17 category boys' school attendance was generally better than the girl's. By location, boys did better in Otavalo, Cuenca's distribution was very similar for both genders, and in Ambato a slight advantage for the girls was observed, though their decreasing school attendance rate.

\section{School attendance: Summary}

The overall school attendance rates of this sample of USWs showed were found to be better than those in other studies on underage workers (Wright et al., 1993; Cuvi et al., 1989; Andrade, 1986). However, the Ecuadorian USWs affiliated with Programa Trabajadores Prematuros are still 
disadvantaged in school enrollment compared to the overall national rates.

By the end of the 18 month follow-up period, no sharp changes were observed in school attendance rates of the USWs. One characteristic of the sample was that elementary school attendance was relatively high, whereas high school attendance was rather poor. Considerably more USWs under than over the age of 12 were going to school.

A look at school attendance by gender showed that more girls than boys were going to school during the 18 month period. The differences between the male and female school attendance were more pronounced at the elementary level, and narrowed at the high school level with boys actually gaining a slight advantage by the follow-up period.

Taking into account the location variable, Cuenca had a very high number of USWs going to school, while USWs in Ambato and Otavalo showed lower percentages. In Cuenca school attendance increased the most during the follow-up period, in Otavalo it increased slightly but still remained far behind that of Cuenca; in Ambato attendance had decreased by the end of follow-up period. 


\section{SCHOOL ACHIEVEMENT}

Several studies point out that the working activities of underage workers impact their performance at school in different ways. Shiefelbein (1985) points out the relationship between impoverished children and lower school performance in Latin America. According to this author, many countries in Latin America have been able to provide schooling for a high proportion of the school age population; however, there are also high failure and drop out rates. In Ecuador, there are no studies that compare the school achievement of USWs and non working children, but research done on Ecuadorian USWs repeatedly shows their poor school achievement (Presidencia, 1992; UNICEF/DYA, 1992; Marquez, 1990; CEDEJOTAIUNICEF, 1989). Rodriguez (1993), who asked teachers about USWs' school attendance and achievement, reports that their general perception was that USWs attended school less and had lower achievement than non working children. Garcia and Hernandez see level repetition, drop out rates and underage work as related problems among poor families. According to Tapia $(1984)^{29}$ and Salazar $(1989)^{30}$, the working activities of

\footnotetext{
${ }^{29}$ Tapia studied underage worker-students in two Ecuadorian cities.

${ }^{30}$ Salazar studied the relationship between underage work and informal work in Ecuador.
} 
USWs are exhausting and impact their school achievement ${ }^{31}$. The study by UNICEF and OIT (1994) argues that in environments where underage work is perceived as natural, school, in terms of time, is a marginal activity for USWs and becomes an obstacle to working. In such a scenario, this report goes on, school failure reinforces child involvement in the labor market. On the other hand, as Fink (1989) highlights, formal schooling has social legitimacy and thus is perceived as desirable for both parents and children; most of them see completion of the elementary level as the minimal educational goal that must be accomplished.

This study does not provide information about repetition rates, but does describe the USWs' school performance throughout 18 months. This span of time was enough to give a clear idea of the USWs' school success or failure. As already mentioned in the Methodology chapter, the findings on school achievement refer only to USWs who were attending elementary school (346 subjects, who represent $84 \%$ of the sample), as records of the school achievement of the high school USWs are not kept by the Program.

School achievement will be examined in its general context first, and then, by gender, location and age. The four follow-up evaluations are taken into account to provide a thorough view of achievement and to observe the different patterns the group exhibits by gender and location.

\footnotetext{
${ }^{31}$ Similar findings are reported by Oloko (1988) in her study on underage traders in urban settings in Nigeria.
} 
School achievement, like school attendance, showed no considerable differences by gender, whereas significant variation was seen by location and age. A trend towards improvement was observed; at the base line $60 \%$ of USWs had satisfactory achievement. In the three subsequent following evaluations, the percentage of USWs with satisfactory achievement increased steadily, reaching $70 \%$ in the last follow-up (see Table 17).

TABLE 17.

SCHOOL ACHIEVEMENT BY BASE LINE AND EVALUATION PERIODS

\begin{tabular}{|l|c|c|c|c|c|c|c|c|}
\hline \multirow{2}{*}{$\begin{array}{l}\text { SCHOOL } \\
\text { ACHIEVEMENT }\end{array}$} & \multicolumn{2}{|l|}{ BASE LINE } & \multicolumn{2}{c|}{ EVALUATION } & \multicolumn{2}{c|}{ EVALUATION } & \multicolumn{2}{c|}{ EVALUATION } \\
\cline { 2 - 9 } & No. & $\%$ & No. & $\%$ & No. & $\%$ & No. & $\%$ \\
\hline A-C & 156 & $60 \%$ & 166 & $64 \%$ & 164 & $65 \%$ & 159 & $70 \%$ \\
\hline D - F & 105 & $40 \%$ & 95 & $36 \%$ & 87 & $35 \%$ & 69 & $30 \%$ \\
\hline TOTAL & 261 & $100 \%$ & 261 & $100 \%$ & 251 & $100 \%$ & 228 & $100 \%$ \\
\hline
\end{tabular}

School Achievement by Age.

There is little research to date on school achievement of underage workers by age. The available information regarding the school performance of impoverished children shows that the number of dropouts increases steadily after 12 years of age (Presidencia, 1992). The increase in dropouts plus the age at which it occurs would lead one to think that impoverished children over 12 years of age tend to have lower school achievement, and 
therefore educationally delayed. An example of this situation in the present study were the USWs over 12 at the beginning of the study period $(\mathrm{N}=47)$ who were still attending elementary school as they had not yet fulfill the requirements to go on to the next level (see Table 18). In this section the school performance of USWs will be analyzed by age categories to contrast the school achievement of the younger with the older USWs. Again recall that school achievement is reported only on USWs attend elementary school.

The relationship between age and school achievement was not found to be significant at the base line $(p<.49194)$, but significant at the last evaluation $(p<.04193[p<.05])$

At the beginning of the study, the school achievement of both age categories was somewhat similar; but by the end of the follow-up period, the difference became sharp: the younger USWs (5 to 11 years old) did better at school than the older USWs (12 to 17 years old).

Age 5 to 11 . USWs with satisfactory school achievement improved from $61 \%$ at the base line to $71 \%$ at the third evaluation. By the end of the follow-up period, nearly three quarters of the group had acceptable grades.

Age 12 to 17 . At the base line, more than half $(55 \%)$ had satisfactory achievement. By the end of the follow-up period, these figures had barely changed, except for a slight increase in the number of USWs with satisfactory achievement (58\%). 
TABLE 18.

SCHOOL ACHIEVEMENT OF USWS BY AGE

\begin{tabular}{|l|c|c|c|c|c|c|c|c|}
\hline \multirow{2}{*}{$\begin{array}{l}\text { SCHOOL } \\
\text { ACHIEVEMENT }\end{array}$} & \multicolumn{4}{|c|}{5 to 11} & \multicolumn{4}{c|}{12 to 17} \\
\cline { 2 - 9 } & BASE LINE & \multicolumn{2}{|c|}{ FOLLOW-UP } & \multicolumn{2}{c|}{ BASE LINE } & \multicolumn{2}{c|}{ FOLLOW-UP } \\
\cline { 2 - 9 } & No. & $\%$ & No. & $\%$ & No. & $\%$ & No. & $\%$ \\
\hline A - C & 130 & $61 \%$ & 144 & $71 \%$ & 26 & $55 \%$ & 15 & $58 \%$ \\
\hline D - F & 84 & $39 \%$ & 58 & $29 \%$ & 21 & $45 \%$ & 11 & $42 \%$ \\
\hline TOTAL & 214 & $100 \%$ & 202 & $100 \%$ & 47 & $100 \%$ & 26 & $100 \%$ \\
\hline
\end{tabular}

When breaking the 12 to 17 year old group into smaller categories (12$13,14-15,16-17)$, it was observed that school achievement rates of the 12-13 year old USWs barely changed for this group; slightly over half of them received unsatisfactory grades (see Table 19). The 14-15 year old group showed considerably better achievement than the 12-13 year olds, however, USWs with satisfactory school achievement decreased. The only subject attending elementary school in the oldest category was performing satisfactorily at school.

Differences between age categories: Summary. At the base line, USWs age 5 to 11 and the 12 to 17 exhibited similar school achievement; the younger USWs were doing better than the older ones but the difference was not wide. By the end of the 18 month follow-up period, a clear difference appeared between the two age categories; while the older group barely 
improved at all, the younger group showed a fair increase in the number of USWs with satisfactory achievement. The overall school achievement and school attendance rates were less positive for the 12 to 17 year old USWs than for the younger group. However, when looking at USWs 12 and older broken into smaller categories, the data showed that the 14-15 year old had achievement rates as good or better as the 5 to 11 USWs, and that the 12-13 year old exhibited the lowest ones.

One possible interpretation of the improvement in school attendance and achievement of USWs under 12 years of age, is that it is related to the impact of the school reinforcement plan applied by the Program to USWs under age 12 with school achievement difficulties.

\section{School Achievement by Location.}

There are no specific studies about school achievement of USWs in the sample locations, except for the research done on Cuenca USWs (Balarezo, 1988), reporting that USWs have significantly lower school achievement (although no quantitative data is presented).

The findings from this study concerning achievement by location showed the relationship between these two variables to be significant. The sample locations showed considerable differences; Cuenca, as in school attendance, exhibited the highest percentage of USWs with satisfactory achievement. The USWs in Ambato occupied second place; almost two thirds 
TABLE19.

SCHOOL ACHIEVEMENT OF USWS OLDER THAN 12

\begin{tabular}{|c|c|c|c|c|c|c|c|c|c|c|c|c|}
\hline \multirow{3}{*}{$\begin{array}{l}\text { SCHOOL } \\
\text { ACHIEVEMENT }\end{array}$} & \multicolumn{4}{|c|}{$12-13$} & \multicolumn{4}{|c|}{$14-15$} & \multicolumn{4}{|c|}{$16-17$} \\
\hline & \multicolumn{2}{|c|}{ BASE LINE } & \multicolumn{2}{|c|}{ FOLLOW-UP } & \multicolumn{2}{|c|}{ BASE LINE } & \multicolumn{2}{|c|}{ FOLLOW-UP } & \multicolumn{2}{|c|}{ BASE LINE } & \multicolumn{2}{|c|}{ FOLLOW-UP } \\
\hline & No. & $\%$ & No. & $\%$ & No. & $\%$ & No. & $\%$ & No. & $\%$ & No. & $\%$ \\
\hline$A-C$ & 18 & $49 \%$ & 7 & $47 \%$ & 8 & $80 \%$ & 7 & $70 \%$ & 0 & $0 \%$ & 1 & $100 \%$ \\
\hline$D-F$ & 19 & $51 \%$ & 8 & $53 \%$ & 2 & $20 \%$ & 3 & $30 \%$ & 0 & $0 \%$ & 0 & $0 \%$ \\
\hline TOTAL & 37 & $100 \%$ & 15 & $100 \%$ & 10 & $100 \%$ & 10 & $100 \%$ & 0 & $0 \%$ & 1 & $100 \%$ \\
\hline
\end{tabular}


had average or better grades. In sharp contrast with these findings, two thirds of the USWs in Otavalo had unsatisfactory school achievement.

Otavalo. While Otavalo's USWs had the lowest rate of average or above achievement, this is the location where USWs school achievement improved the most (see Table 20).

At the beginning of the study, only slightly more than a fifth of the USWs $(23 \%)$ had satisfactory achievement; this increased to $32 \%$ at the first evaluation. By the second evaluation, the USWs school achievement increased to $42 \%$. But, at the third follow-up, it declined to $34 \%$, still an improvement over the base line rate. (It should be taken into account, though, that Otavalo has the smallest sample, and thus the changes in the achievement of several students may notably affect percentages).

TABLE 20.

SCHOOL ACHIEVEMENT OF USWS IN OTAVALO BY TIME PERIOD

\begin{tabular}{|c|c|c|c|c|c|c|c|c|}
\hline \multirow[t]{2}{*}{$\begin{array}{l}\text { ScHOOL } \\
\text { ACHEVEMENT }\end{array}$} & \multicolumn{2}{|c|}{ BASE LINE } & \multicolumn{2}{|c|}{$\begin{array}{c}\text { EVALUATION } \\
1 \\
\end{array}$} & \multicolumn{2}{|c|}{$\begin{array}{c}\text { EVALUATION } \\
2 \\
\end{array}$} & \multicolumn{2}{|c|}{$\begin{array}{c}\text { EVALUATION } \\
3 \\
\end{array}$} \\
\hline & No. & $\%$ & No. & $\%$ & No. & $\%$ & No. & $\%$ \\
\hline$A-C$ & 8 & $23 \%$ & 11 & $32 \%$ & 15 & $42 \%$ & 12 & $34 \%$ \\
\hline$D-F$ & 27 & $77 \%$ & 23 & $68 \%$ & 21 & $58 \%$ & 23 & $66 \%$ \\
\hline TOTAL & 35 & $100 \%$ & 34 & $100 \%$ & 36 & $100 \%$ & 35 & $100 \%$ \\
\hline
\end{tabular}


Ambato. The school achievement of USWs from Ambato showed a pattern different from that of the USWs from Otavalo. The USWs' school achievement rate barely changed in this location during the measurement period; at the base line, $63 \%$ had satisfactory achievement, the percentage dropped slightly in the two intermediate evaluations, and increased to $67 \%$ at the last one (see Table 21).

Cuenca. As seen in school attendance, Cuenca had a substantial percentage of USWs with satisfactory school achievement (see Table 22). In this location there was an overall trend towards improvement. Compared to the base line percentage (68\%), the first, second and third evaluations exhibited higher percentages ( $81 \%, 77 \%, 84 \%$ respectively).

\section{TABLE 21.}

SCHOOL ACHIEVEMENT OF USWS IN AMBATO BY TIME PERIOD

\begin{tabular}{|l|c|c|c|c|c|c|c|c|}
\hline \multirow{2}{*}{$\begin{array}{l}\text { scHOOL } \\
\text { ACHEVEMENT }\end{array}$} & \multicolumn{2}{|l|}{ BASE LINE } & \multicolumn{2}{|c|}{\begin{tabular}{c} 
EVALUATION \\
\multicolumn{2}{|c|}{}
\end{tabular}} & \multicolumn{2}{|c|}{ EVALUATION } & \multicolumn{2}{|c|}{ EVALUATION } \\
\cline { 2 - 9 } & No. & $\%$ & No. & $\%$ & No. & $\%$ & No. & $\%$ \\
\hline A - C & 79 & $63 \%$ & 67 & $57 \%$ & 64 & $61 \%$ & 58 & $67 \%$ \\
\hline D - F & 46 & $37 \%$ & 51 & $43 \%$ & 41 & $39 \%$ & 29 & $33 \%$ \\
\hline TOTAL & 125 & $100 \%$ & 118 & $100 \%$ & 105 & $100 \%$ & 87 & $100 \%$ \\
\hline
\end{tabular}


TABLE 22.

SCHOOL ACHIEVEMENT OF USWS IN CUENCA BY TIME PERIOD

\begin{tabular}{|l|c|c|c|c|c|c|c|c|}
\hline \multirow{2}{*}{$\begin{array}{l}\text { school } \\
\text { ACHEVEMEN }\end{array}$} & \multicolumn{2}{|l|}{ BASE LINE } & \multicolumn{2}{|c|}{\begin{tabular}{c} 
EVALUATION \\
\multicolumn{2}{|l|}{}
\end{tabular}} & \multicolumn{2}{|c|}{ EVALUATION } & \multicolumn{2}{|c|}{ EVALUATION } \\
\cline { 2 - 9 } & No. & $\%$ & No. & $\%$ & No. & $\%$ & No. & $\%$ \\
\hline A - C & 69 & $68 \%$ & 88 & $81 \%$ & 85 & $77 \%$ & 89 & $84 \%$ \\
\hline D - F & 32 & $32 \%$ & 21 & $19 \%$ & 25 & $23 \%$ & 17 & $16 \%$ \\
\hline TOTAL & 101 & $100 \%$ & 109 & $100 \%$ & 110 & $100 \%$ & 106 & $100 \%$ \\
\hline
\end{tabular}

Differences between locations. Comparing the school achievement of USWs in the three locations, all of them showed improvement during the measurement period: with considerable gains in Otavalo and Cuenca and a small gain in Ambato. Otavalo USWs improved by $50 \%$ between the base line and the third evaluation, Cuenca USWs by nearly $25 \%$, and Ambato USWs by $6 \%$.

Overall, Cuenca had more USWs with better achievement during all the measurement periods than the other two locations. Ambato occupied second place, and Otavalo, third, in spite of the USWs improvement.

School Achievement by Gender.

Regarding women, Stromquist (1992) asserts that other issues have been researched in Latin America, but women's education remains relatively 
unexamined. Data on school enrollment in the region shows:

... a tendency toward gender parity. The differential between men's and women's enrollments is minimal at the primary school level and small at the secondary school level. The gender gap is slightly more sizable at the university level... (Stromquist, 1992, p.1).

Data on elementary school grade repetition indicate that women fail and repeat by the same proportion or slightly less than men (UNESCO, 1988). But, females tend to drop out in larger number than males (Stromquist, 1992).

Studies done in Ecuador report on several issues about female school performance: The UNICEF/DYA (1992) study found that girls' school achievement is affected by discriminatory treatment by teachers which orients students towards gender "appropriate" careers. Moreover, Moser (1989) argues that poor girls have less time for school work because of the overburden of their domestic responsibilities, due to their mother's involvement in productive activities.

The findings from this study show no considerable differences in school achievement between female and male USWs. When gender was correlated with school achievement, the relationship was found not significant in any of the four evaluations (Base line: $p<.63557$; Evaluation 1: $p<.78677$; Evaluation 2: $p<.87854$; Evaluation 3: $p<.85088)$. As with school attendance, the hypothesis that the rate of school 
achievement would be lower for female USWs than for male USWs was not supported. Girls and boys exhibited similar school achievement, and both groups showed a trend towards improvement. About two thirds of each group were doing well at school during the study; at the base line $61 \%$ of the girls and $58.5 \%$ of the boys had satisfactory school achievement and, by the end of the measurement period, the percentage of the male and female USWs with satisfactory achievement increased to $69 \%$ for the girls and $70 \%$ for the boys (see Tables 23 and 24).

TABLE 23.

FEMALE USWs SCHOOL ACHIEVEMENT

\begin{tabular}{|c|c|c|c|c|c|c|c|c|}
\hline \multirow[t]{2}{*}{$\begin{array}{l}\text { SCHOOL } \\
\text { ACHEVEMENT }\end{array}$} & \multicolumn{2}{|c|}{ BASE LINE } & \multicolumn{2}{|c|}{$\begin{array}{c}\text { EVALUATION } \\
1 \\
\end{array}$} & \multicolumn{2}{|c|}{$\begin{array}{c}\text { EVALUATION } \\
2 \\
\end{array}$} & \multicolumn{2}{|c|}{$\begin{array}{c}\text { EVALUATION } \\
3 \\
\end{array}$} \\
\hline & No. & $\%$ & No. & $\%$ & No. & $\%$ & No. & $\%$ \\
\hline$A-C$ & 70 & $61 \%$ & 71 & $64.5 \%$ & 70 & $65 \%$ & 67 & $69 \%$ \\
\hline$D-F$ & 44 & $39 \%$ & 39 & $35.5 \%$ & 38 & $35 \%$ & 30 & $31 \%$ \\
\hline TOTAL & 114 & $100 \%$ & 110 & $100 \%$ & 108 & $100 \%$ & 97 & $100 \%$ \\
\hline
\end{tabular}


TABLE 24.

MALE USWS SCHOOL ACHIEVEMENT

\begin{tabular}{|c|c|c|c|c|c|c|c|c|}
\hline \multirow[t]{2}{*}{$\begin{array}{l}\text { SCHOOL } \\
\text { ACHEVEMENT }\end{array}$} & \multicolumn{2}{|c|}{ BASE LINE } & \multicolumn{2}{|c|}{$\begin{array}{c}\text { EVALUATION } \\
1\end{array}$} & \multicolumn{2}{|c|}{$\begin{array}{c}\text { EVALUATION } \\
2\end{array}$} & \multicolumn{2}{|c|}{$\begin{array}{c}\text { EVALUATION } \\
3\end{array}$} \\
\hline & No. & $\%$ & No. & $\%$ & No. & $\%$ & No. & $\%$ \\
\hline$A-C$ & 86 & $58.5 \%$ & 95 & $63 \%$ & 94 & $66 \%$ & 92 & $70 \%$ \\
\hline$D-F$ & 61 & $41.5 \%$ & 56 & $37 \%$ & 49 & $34 \%$ & 39 & $30 \%$ \\
\hline TOTAL & 147 & $100 \%$ & 151 & $100 \%$ & 143 & $100 \%$ & 131 & $100 \%$ \\
\hline
\end{tabular}

Female USWs. The female USWs improved their school achievement in a moderate but steady pace at each evaluation. When looking at the female school achievement by age, a small increase in satisfactory school achievement rates of the 5 to 11 year olds girls was observed, whereas the 12 to 17 year old girls exhibited considerable improvement theirs during the course of the study (see Table 25).

Looking at the girls' school achievement by location, it was observed that in Otavalo, although some improvement in school achievement was made by the girls, their school achievement was still very poor; $92 \%$ of the female USWs at the base line and $75 \%$ of them at the follow-up had unsatisfactory school achievement (see Table 26). Ambato had relatively high rate of girls with satisfactory school achievement that barely changed during the followup period. Finally, Cuenca exhibited the highest rate of satisfactory school 
achievement at the base line, which increased even more during the measurement period.

TABLE 25

FEMALE USWs SCHOOL ACHIEVEMENT BY AGE

\begin{tabular}{|l|c|c|l|l|l|l|l|l|}
\hline \multirow{2}{*}{$\begin{array}{l}\text { SCHOOL } \\
\text { ACHIEVEMENT }\end{array}$} & \multicolumn{4}{|c|}{5 to 11} & \multicolumn{4}{c|}{12 to 17} \\
\cline { 2 - 9 } & BASE LINE & FOLLOW-UP & \multicolumn{1}{|c|}{ BASE LINE } & \multicolumn{2}{|c|}{ FOLLOW-UP } \\
\cline { 2 - 9 } & No. & $\%$ & No. & $\%$ & No. & $\%$ & No. & $\%$ \\
\hline A - C & 64 & $64 \%$ & 62 & $69 \%$ & 6 & $43 \%$ & 5 & $71 \%$ \\
\hline D - F & 36 & $36 \%$ & 28 & $31 \%$ & 8 & $57 \%$ & 2 & $29 \%$ \\
\hline TOTAL & 100 & $100 \%$ & 90 & $100 \%$ & 14 & $100 \%$ & 7 & $100 \%$ \\
\hline
\end{tabular}

Male USWs. When looking at the male school achievement by age, it was observed that the percentage of 5 to 11 year old boys with satisfactory achievement increased from $58 \%$ to $73 \%$ during the measurement period, while the 12 to 17 year olds doing well at school decreased from $61 \%$ to $53 \%$ (see Table 27). 
TABLE 26.

SCHOOL ACHIEVEMENT OF FEMALE USWS BY LOCATION

\begin{tabular}{|c|c|c|c|c|c|c|c|c|c|c|c|c|}
\hline \multirow{3}{*}{$\begin{array}{l}\text { SCHOOL } \\
\text { ACHIEVEMENT }\end{array}$} & \multicolumn{4}{|c|}{ OTAVALO } & \multicolumn{4}{|c|}{ AMBATO } & \multicolumn{4}{|c|}{ CUENCA } \\
\hline & \multicolumn{2}{|c|}{ BASE LINE } & \multicolumn{2}{|c|}{$\begin{array}{l}\text { FOLLOW- } \\
\text { UP }\end{array}$} & \multicolumn{2}{|c|}{ BASE LINE } & \multicolumn{2}{|c|}{$\begin{array}{l}\text { FOLLOW- } \\
\text { UP }\end{array}$} & \multicolumn{2}{|c|}{ BASE LINE } & \multicolumn{2}{|c|}{$\begin{array}{l}\text { FOLLOW- } \\
\text { UP }\end{array}$} \\
\hline & No. & $\%$ & No. & $\%$ & No. & $\%$ & No. & $\%$ & No. & $\%$ & No. & $\%$ \\
\hline$A-C$ & 1 & $8 \%$ & 3 & $25 \%$ & 30 & $64 \%$ & 18 & $62 \%$ & 39 & $71 \%$ & 46 & $82 \%$ \\
\hline$D-F$ & 11 & $92 \%$ & 9 & $75 \%$ & 17 & $36 \%$ & 11 & $38 \%$ & 16 & $29 \%$ & 10 & $18 \%$ \\
\hline TOTAL & 12 & $100 \%$ & 12 & $100 \%$ & 47 & $100 \%$ & 29 & $100 \%$ & 55 & $100 \%$ & 56 & $100 \%$ \\
\hline
\end{tabular}


TABLE 27.

MALE USWS SCHOOL ACHIEVEMENT BY AGE

\begin{tabular}{|l|c|c|l|l|l|l|l|l|}
\hline \multirow{2}{*}{$\begin{array}{l}\text { SCHOOL } \\
\text { ACHIEVEMENT }\end{array}$} & \multicolumn{4}{|c|}{5 to 11} & \multicolumn{4}{c|}{12 to 17} \\
\cline { 2 - 9 } & BASE LINE & FOLLOW-UP & \multicolumn{2}{|c|}{ BASE LINE } & FOLLOW-UP \\
\cline { 2 - 9 } & No. & $\%$ & No. & $\%$ & No. & $\%$ & No. & $\%$ \\
\hline A - C & 66 & $58 \%$ & 82 & $73 \%$ & 20 & $61 \%$ & 10 & $53 \%$ \\
\hline D - F & 48 & $42 \%$ & 30 & $27 \%$ & 13 & $39 \%$ & 9 & $47 \%$ \\
\hline TOTAL & 114 & $100 \%$ & 112 & $100 \%$ & 33 & $100 \%$ & 19 & $100 \%$ \\
\hline
\end{tabular}

As shown in Table 28, male school achievement by location was patterned as follows: the rate of boys in Otavalo with satisfactory achievement was quite low, although it had increased some by the last follow-up period. In Ambato, about two thirds of the boys had satisfactory school achievement at the base line, and this increased to $69 \%$ by the end of the follow-up. Boys in Cuenca improved their school achievement rate even more than in the other locations; the percentage of males with satisfactory grades increased from $65 \%$ to $86 \%$ during the study.

Differences between male and female USWs. Few differences were observed between the school achievement of female and male USWs. Boys and girls achieved equally at school, except for a minimal difference that showed females doing slightly better at school than the boys at the beginning of the follow-up period, whereas, at the end of that period, the relationship 
TABLE 28.

SCHOOL ACHIEVEMENT OF MALE USWS BY LOCATION

\begin{tabular}{|c|c|c|c|c|c|c|c|c|c|c|c|c|}
\hline \multirow{3}{*}{$\begin{array}{l}\text { SCHOOL } \\
\text { ACHIEVEMENT }\end{array}$} & \multicolumn{4}{|c|}{ OTAVALO } & \multicolumn{4}{|c|}{ AMBATO } & \multicolumn{4}{|c|}{ CUENCA } \\
\hline & \multicolumn{2}{|c|}{ BASE LINE } & \multicolumn{2}{|c|}{$\begin{array}{l}\text { FOLLOW- } \\
\text { UP }\end{array}$} & \multicolumn{2}{|c|}{ BASE LINE } & \multicolumn{2}{|c|}{$\begin{array}{l}\text { FOLLOW- } \\
\text { UP }\end{array}$} & \multicolumn{2}{|c|}{ BASE LINE } & \multicolumn{2}{|c|}{$\begin{array}{l}\text { FOLLOW- } \\
\text { UP }\end{array}$} \\
\hline & No. & $\%$ & No. & $\%$ & No. & $\%$ & No. & $\%$ & No. & $\%$ & No. & $\%$ \\
\hline$A-C$ & 7 & $30 \%$ & 9 & $39 \%$ & 49 & $63 \%$ & 40 & $69 \%$ & 30 & $65 \%$ & 43 & $86 \%$ \\
\hline$D-F$ & 16 & $70 \%$ & 14 & $61 \%$ & 29 & $37 \%$ & 18 & $31 \%$ & 16 & $35 \%$ & 7 & $14 \%$ \\
\hline TOTAL & 23 & $100 \%$ & 23 & $100 \%$ & 78 & $100 \%$ & 58 & $100 \%$ & 46 & $100 \%$ & 50 & $100 \%$ \\
\hline
\end{tabular}


was reversed.

The male and female USWs age 5 to 11 both improved their school achievement during the study, however, while the girls were doing better at school than the boys at the base line, the boys improved more than the girls by the end of the measurement period. The 12 to 17 year old girls exhibited a notable increase in satisfactory achievement rates while the boys' rate decreased some.

Looking at the differences in the school achievement of the boys and girls by location, it was observed that the boys' rate of satisfactory achievement increased during the study in all locations while the girl's increased in Otavalo and Cuenca and decreased slightly in Ambato. In Ambato boys made more improvement in school achievement than did girls. In Cuenca although the girls' achievement was higher than the boys', by the end of the study, the latter surpassed the girls'.

School Achievement: Summary.

Recapitulating, an outstanding characteristic of the school achievement of the sample subjects was its trend towards improvement during the 18 month follow-up period.

School achievement of USWs by age showed the two age categories with a similar school performance at the beginning of the study. Yet, by the end of it, the younger group clearly was doing better at school than the older 
group.

By gender, school achievement rates of USWs exhibited no significant differences; both groups improved their achievement during the follow-up period. Considerable differences appeared by location; all three sites showed increases in the percentage of USWs with satisfactory school achievement. Taking into account the overall school achievement percentages, USWs in Cuenca exhibited the best ones, USWs in Otavalo the poorest ones, and Ambato USWs were in between. Looking at improvement in school achievement accomplished by USWs in each location during the follow-up period, USWs in Otavalo and Cuenca improved considerably, yet the former was still far behind the school achievement levels in Cuenca and Ambato. Finally, the school achievement rate of USWs in Ambato, though showing a very small increase, barely changed during the 18 month follow-up period. 


\section{CHAPTER V}

\section{DISCUSSION OF THE FINDINGS}

\section{SCHOOL ATTENDANCE}

In this research, the school attendance of the USWs showed little variation during the measurement period; two thirds of the sample attended school at the beginning and end of the study. Another characteristic of the USWs' educational behavior was the substantial number of them who were attending elementary school: $75 \%$ of the USWs who had not completed the elementary level were attending elementary school, while only $15 \%$ of those who had completed elementary school were attending high school. The data showed also that school attendance of the USWs under the age of 12 was double that of USWs older than 12. A fifth of USWs over age 12 were educationally delayed and were still attending elementary school, while a quarter of them had not finished the elementary level and were not attending school.

The USWs school attendance by location showed that four fifths of Cuenca's sample subjects were going to school, while only two thirds of 
the subjects in Ambato and Otavalo were attending school. Furthermore, in Cuenca, USWs' school attendance increased the most during the study. Otavalo USWs' attendance increased slightly but remained far behind Cuenca, while the attendance of Ambato USWs decreased by the end of the follow up period.

By gender, the data showed that more girls than boys were going to school during the 18 month follow-up. The advantage in school attendance of the females over the males was noticeable at the elementary level, whereas at high school there was actually no real differences.

Studies on underage workers in Ecuador that provide information about USWs' school attendance, report higher non attendance rates than this research. The study by Cuvi et al. (1989) of an intervention population of USWs, found that $48 \%$ did not attend school. UNICEF and OIT (1994) reported that half of underage workers did not attend school. Additionally, other studies that do not provide any specific data stress the point that fewer underage workers go to school than non working children (Presidencia, 1992; Salazar 1989; Tapia, 1984; Balarezo, 1981). Finally, Wright et al. (1993) in their study on USWs in Honduras report similar school attendance rates $(48 \%)$ to the ones found in Ecuador. One possible interpretation of the difference in school attendance 
rates between the studies mentioned and this research is that age and location statuses of the population of this study may in part account for its higher school attendance rates of this sample. The relatively young age of the subjects in the sample (two thirds were 5 to 11 years) plus the high overall rate of school attendance of this young group (it was double that of the 12 to 17 year olds) affects the overall rate. The data also showed significant differences by location; the USWs in Cuenca exhibited noticeably high overall school attendance rates, while the USWs in Ambato and Otavalo showed lower ones, similar to those found in the studies mentioned. Therefore, the strong school attendance rate of the younger USWs and of the USWs in Cuenca can partially explain the difference in school attendance rates between this sample and the other studies mentioned.

Despite the impact of the working activities on the USWs' school attendance (MRHT et al. 1994; UNICEF/OIT, 1994), the data from this study showed stable levels of school attendance during the 18 month follow-up. Moreover, school attendance rates of the USWs barely changed during the study, which means that they did not drop out from school as much as expected ${ }^{32}$. One possible interpretation of the stable

\footnotetext{
population.

${ }^{32}$ Presidencia (1992) and UNICEF/OIT (1992) report high dropout rates for this
} 
attendance rates is that they are related to the Program's intervention. A comparison with a non intervention population would be needed to confirm this point; however, because the Program specifically addresses school attendance and retention issues, it is possible that if there were no intervention, there would have been notable declines in the USWs' school attendance rate. Of course, it is also possible that the 18 month follow-up period was too short to observe changes in the school attendance of the sample.

Another useful indicator of the educational levels of USWs are elementary school completion rates (Stromquist, 1992). In the present study, the overall elementary school completion rate increased, as did all rates within status categories (age, location and gender). These increased rates of elementary school completion were probably an effect of the USWs stable school attendance rates and a positive indicator of their achievement during the follow-up las already seen, school achievement showed a trend towards improvement). They may also indicate that the Program is having some success in retaining the USWs in school, at the very least until completion of the elementary level ${ }^{33}$.

By age. The USWs school attendance rates seen by age categories

\footnotetext{
${ }^{33}$ Recall that the Program emphasizes the importance of the USWs' completion of the elementary level.
} 
showed a sharp difference between the 5 to 11 year olds and the 12 to 17 year olds; while by the end of the study, only $20 \%$ of the former were not attending school, two thirds of the latter were not. Out of the 133 USWs older than 12 who, according to their age, should have been going to high school, $5 \%$ were attending at the base line, and $15 \%$ by the end of the follow-up (some increase, but still a low rate). The low high school attendance pattern did not change when the 12 to 17 group was broken into smaller categories, but exhibited a similar educational delay. Other studies report similar findings about the poor school attendance of USWs older than 12. According to Cuvi et al. (1989) $81 \%$ of the $14-17$ year olds did not attend school and $68.8 \%$ were educationally delayed by 2 or more years. They also point out that the trend for this population is not to attend high school, but at best complete the elementary level. Andrade (1986) found that only $16 \%$ of USWs above the age of 12 went to high school. Also, the assessment of Ecuadorian children done by Presidencia (1992a) asserts that dropout rates increase steadily after age 12. Finally, in Peru, Mancilla (1988), in her study on child work in Lima, found that dropping out of school increases at age 10 , which is the average age that Peruvian children enter the labor market.

The differences in school attendance rates found between the two age categories lead one to think that school is more accessible to younger 
than oider USWS (Presidencia, 1992a). As mentioned in the literature review, the educational system commonly lets the students go if they have a failed a grade. This is likely to be the case for many of the 12 to 17 year old USWs (UNICEF/OIT, 1994). Additionally, USWs' parents seem to be more inclined to send the younger children to school to provide them with some years of schooling (Garcia and Hernandez, 1992), whereas the older children are needed to contribute to the family income.

For the 12 to 17 years old USWs, it may be possible that increased involvement in the labor market and the record of school failure and dropout they have accumulated by this age becomes an obstacle to further school attendance (MRHT et al, 1994; UNICEF/OIT, 1994, Presidencia, 1992a; UNICEF/DYA, 1992). As the USWs grow older, their involvement in productive activities usually increases (INEC, 1991), because there's more family pressure on older children to bring a certain amount of money to their home units daily (Mancilla, 1988; Tacon, 1988). Besides, if the USWs do not work they can not pay for school expenses but, work affects their school achievement (Mancilla 1988; Tapia, 1984, Salazar, 1989), Dropping out, failure and level repetition are common among USWs (Presidencia, 1992). Failure and level repetition not only frustrate the children (Tapia, 1984) but stigmatize them and 
frequently reduce their chances of getting re-enrolled in school. All in all, the USWs' situation turns into a pattern which is difficult to reverse modify.

All indicators (except for a small increase in high school attendance) of the school attendance of the 12 to 17 year old USWs in the sample showed their educational delay. The school attendance distribution did not change when the 12 to 17 year old group was broken into smaller categories; each of them exhibited lower school attendance rates than the 5 to 11 year olds. However, some interesting differences were observed between age sub-groups within the 12-17 age (although some caution in interpreting must be exercised due to the small number of respondents in some of the sub-groups). At the base line, the decline in school attendance was steady as age increased. However, this situation changed by the end of the study; the school attendance rates of the $14-15$ and $16-17$ year old USWs increased and were notably similar to those of the 12-13 year olds. In fact, the school attendance rate of the 14-15 year olds was slightly higher than that of the $12-13$ year olds. This school attendance distribution allows for the speculation that age 12-13 is a sort of turning point for school attendance because of the sharp drop that occurred there in the study. The improvement in school attendance rates of the 14 to 17 year old USWs seen by the end of the study, may 
be interpreted as related to the Program's intervention. There is insufficient information to explain why the Program might be impacting the 14-17 year old USWs positively, but not the $12-13$ year old USWs. It is possible though, that if this is a peak age, it may be harder to affect it than to affect those who have made it past that point.

By location. One way of interpreting the differences found in school attendance by location is to use the common argument that the conditions of USWS are harsher in larger cities ${ }^{34}$. If this argument was applicable to the USW' school attendance in this sample, Cuenca should exhibit the lowest rates ${ }^{35}$. However, the school attendance rates found in Cuenca are higher than those of the other sample sites, and also than the ones in the studies by Cuvi et al. (1989) and Andrade (1986).

A second argument is that locations with similar demographic characteristics should exhibit more similar results. Ambato and Cuenca show more similarities in terms of size of the population, rural/urban make-up, concentration of the province's population in these cities, illiteracy rates, and economically active population rates for the 8-14 year

\footnotetext{
${ }^{34}$ There are no studies comparing the specific conditions of the USWS in different cities of the country. Yet, the literature on USWs lead one to think that their well being is more endangered in larger urban settings. in the country.

${ }^{35}$ Recall that Cuenca is the largest of the three sample sites and the third largest city
} 
olds (INEC, 1991a,b,c). However, school attendance of Ambato and Cuenca USWs were not similar; instead it was the school attendance distribution of the USWs in Ambato and Otavalo that exhibited similarities. Furthermore, USWs school attendance rates in both latter locations were found to be similar to those in locations with totally different demographic indicators, such as Quito (Cuvi et al. 1989). Therefore, it is possible that the findings of this study are explained by location characteristics other than those identified.

One possibility is that the findings are related to specific characteristics of the USW population in each location. Regardless of location, underage work definitely affects the school attendance of USWs in this sample. But, the degree to which it impacts their school attendance may vary depending upon specific characteristics of the USW population in different sites. The USWs in Cuenca exhibited two distinctive attributes which may be associated with their school attendance rate; one is the higher educational levels of their parents (Novillo, 1994), and, the second is the young age of this sample, which as discussed before impacts school attendance. As for an explanation of why Otavalo's and Ambato's USWs school attendance rates were similar, there is not enough information to explain this situation. But again, the similarities between the USWs in Ambato and Otavalo -- older age of the 
subjects, and lower educational levels of the USWs' parents (Novillo, 1994) -- may partially account for their similar (and lower than Cuenca's) rates.

Further research is needed to explain the differences between the sample sites which are not that clear cut. For example, the girls in Ambato and Cuenca showed similar school attendance rates at the base line. However, by the end of the study school attendance rate of Ambato girls drops considerably and resembles that in Otavalo. One possible explanation of this situation is a differential impact of the Program by gender in each location. However, the findings on girls' school achievement did not show a similar pattern. Therefore, if this interpretation is correct, it would mean that the Program is positively affecting the girls' school attendance (but not necessarily school achievement) in certain locations and not in others.

One shortcoming of this study is the lack of data on potentially important variables, for example on the total years of schooling of the subjects, race and ethnicity and socio-economic status of the USWs (in this population and overall), and educational services available in particular locations. This data would have allowed a more accurate analysis and provided a more thorough coverage of variables that might affect USWs' school attendance. Finally, it would also be interesting to 
know to what extent education is valued in these locations. From the available information it may be speculated that it is most valued in Cuenca, while in Ambato and Otavalo it is not valued as much (INEC, $1991 \mathrm{a}, \mathrm{b}, \mathrm{c})$. This is compatible with the findings from Cuenca in this study.

All in all, because of the similar school attendance rates of USWs between two of the sample sites and previous studies, it may be assessed with fair certainty that overall no less than $50 \%$ of USWs go to school in Ecuador.

By gender. The findings on school attendance by gender showed a larger number of girls than boys going to school. The educational advantage for the female USWs in this sample contrasts with the low female school attendance rate reported by Garcia and Hernandez (1992). But, it corroborates the findings by Cuvi et al. (1989) who found no differences between school attendance of male and female USWs. The former's sample consisted of underage workers in general ${ }^{36}$, while the latter's sample was drawn specifically from a USW population. This suggests that female USWs in this sample and in Cuvi et al.'s (1992)

${ }^{36}$ USWs are the smallest category of underage workers in Ecuador (Garcia and Hernandez, 1992). Among these underage workers there is a substantial population of girls working in domestic service and in the fields who are more likely not to attend school (Garcia and Hernandez 1992; Presidencia, 1992; UNICEF/DYA, 1992). 
attend more school than other underage female workers (at least at the elementary level).

Another interpretation, following the literature on access of Latin American women to education, is that the educational gap between males and females at the elementary and high school level has narrowed because of the expansion of educational services (Stromquist, 1992; Acosta, 1989), and that this situation can be observed in the USWs as well as the general population (INEC, 1991). However, despite the relatively high overall school attendance rates observed for the female USWs, the findings from this study should not be interpreted as an absolute advantage for girls. When observing the variations between the base line and the third evaluation, or between age categories or locations, the gender differences became narrower. A closer look at the data reveals other signs of lesser advantage for girls: for example, the similar high school attendance rates for USW boys and girls; the higher rate of school attendance rate of the male 12 to 17 year old USWs, by the end of the study; the sharp drop in school attendance of the 12-13 year old USWs girls; the absence of 14-15 year old girls in high school and the higher elementary completion rate of the male 14-15 year old USWs.

A second possible interpretation of the girls' higher elementary school attendance rates may be that the working activities of the younger 
girls are more compatible with school than the boys' las was found by Ennew [1989] on Peruvian USW $\mathbf{s}^{37}$ ). However, further research is needed to confirm this viewpoint. A third possibility, following Ennew's (1989) argument that Peruvian female USWs place a higher value on education and therefore attend more school, is to argue that Ecuadorian girls also value education more than boys do. Finally, a fourth possible interpretation is that more female USWs attend school because their parents see to it that they attend school on a regular basis ${ }^{38}$. USW girls, unlike USW boys, usually work under the protection of their parents (or an acquaintance) (Boyden 1988). Boys work more independently than girls do (Boyden, 1988), thus, the decision of attending or not attending school is their own and, consequently, dropping out of school might become a more frequent option. In other words the more restricted role of the girls and their limited freedom (Tenorio, 1992; Gissi, 1980; Safa, 1980), work in this situation to their 'advantage', that is, to attend school more than the boys. However, as age increased, particularly when they

${ }^{37}$ Ennew (1988) in her study on Peruvian underage workers found that the malerelated working activities such as car washing and selling newspapers were associated with low school attendance, whereas many of the occupations in which female underage workers are clustered exhibited high correlations with schooling.

\footnotetext{
${ }^{38}$ First hand observations done by the researcher in several towns of the country support this idea.
} 
reached age 12 or 13 , the strong school attendance rate was replaced by a high drop out rate, probably because at this age their parents cannot afford to provide them with more education, and/or because the trend is still to educate boys more than girls (Elhers, 1990; Acosta, 1989;

Stromquist, 1989; Population Reference Bureau, 1986; Charlton, 1984; Nash, 1980).

Further research is needed to shed greater light on the interpretations discussed in this section. One thing that can be argued with fair certainty is that the advantage of the girls in school attendance is not that clear-cut. The girls' overall higher elementary school attendance rates are not conclusive of their educational advantage. 


\section{SCHOOL ACHIEVEMENT}

This study found that a substantial portion of the sample performed well at school. Moreover, the data showed a trend towards improvement during the follow-up period. USW boys and girls exhibited few differences in school achievement during the study, although significant differences appeared according to age and location. At the beginning of the follow-up, the 5 to 11 year and the 12 to 17 year old USWs showed similar school achievement. However, by the end of it, the difference was sharp; the younger USWs' school performance was considerably better than that of the older group. In spite of the overall lower school achievement of the 12 to 17 year olds, there was some variation within this age category in that the 14-15 year olds did as well at school as the 5 to 11 year olds.

In terms of location, USWs in Cuenca exhibited the highest school achievement rate while Otavalo USWs showed the lowest. However, school achievement of USWs in these sites improved considerably during the study, whereas that of Ambato USWs barely changed.

The USWs improvement in school achievement shown in this study contrasts with different studies that point to the lower and deteriorating school achievement of USWs (Rodriguez, 1993; Presidencia, 1992a; UNICEF/DYA, 1992; Marquez, 1990; CEDEJOTA/UNICEF, 1989; Salazar, 
1989; Tapia, 1984). One interpretation is that the more positive situation found in the present study may be related to the Program's intervention in and support of USWs' access to school, and school attendance and achievement, through several strategies. Positively affecting the USWs school achievement might be a school reinforcement plan applied by the Program to all USWs under age 12 who exhibited achievement problems. Although a direct link cannot be confirmed on the basis on this study, Landazuri (1992) in his evaluation report of the Program, points out that improvement in school achievement of the USWs has been one of the main successes of the Program.

By age. The greater improvement in school achievement accomplished by the 5 to 11 year olds during the study, supports the argument that the Program has had a positive impact on the younger USWs' school achievement. Recall that the data showed a significant relation between school achievement and age by the end of the study (both groups exhibited similar school achievement at the base line, whereas, by the end of the 18 months, the youngest group showed a sizable improvement in their school achievement). Therefore, it appears that the school reinforcement program applied to this younger group is affecting their school achievement.

The Program's impact is not the sole explanation for school 
achievement improvement, because, as mentioned earlier, the data showed that the 14-15 year olds, who did not undergo any reinforcement plan, were doing as well as the 5 to 11 year olds. There are no data to explain this situation (moreover, the subgroup of 14-15 year olds was quite small); however, it is interesting to note that school attendance showed a somewhat similar pattern; that is, a sharp decrease at age 12 13 , and then a more stable distribution. In the school achievement distribution, as well as in school attendance, the 12-13 age gap appears as a sort of "peak age", as some of the other literature suggests (Presidencia, 1992d, UNICEF/DYA, 1992). It would be interesting for future studies to pay special attention to this age category to better understand its salience. All in all, the trend towards school achievement improvement is a meaningful outcome, considering that such progress increases the probability the USWs of staying in the educational system ${ }^{39}$.

By location. School achievement by location showed improvement of the USWs in Cuenca and Otavalo. The data showed that school attendance and achievement in the three locations follow a certain trend. The sample sites with improved or stable school attendance rates over

\footnotetext{
${ }^{39}$ Garcia and Hernandez (1992) report that among parents of the USWS the principal reason for allowing their children to drop out of school is the lack of learning abilities of the children. Thus, school success should eventually lead parents to maintain the USWs at school for longer periods of time.
} 
the course of the study (Cuenca and Otavalo) also exhibited improving school achievement rates during the study. Whereas, Ambato USWs, for whom school attendance rates decreased during the study, underwent no changes in their school achievement rates. If this pattern is interpreted as a result of the Program's intervention, then, it follows that the Program is affecting the educational behavior of the USWs in Ambato less positively than in the other two sites. On the other hand, it is possible that the specific characteristics of the USWs in Ambato account for the difference. According to local Program notes, one such distinct characteristic is the greater mobility of the USWs observed in this site; some of the USWs who worked in Ambato came from nearby towns and went back home after work; some did this on a regular basis while others did not. Thus, the Program had difficulty in carrying out its activities, because these USWs had less time to participate in them than USWs who lived in town. To control this situation, the Program attempted to implement its activities in one of these nearby towns, but perhaps this strategy was not effective. Further research, comparing the educational behavior of USWs who lived in Ambato with that of those who lived elsewhere, would be useful. Another possible intervening factor is the size of the population targeted by the local programs, substantially larger in Ambato than in the other two sites. It may be that the Program in 
smaller locations.

As it did with school attendance, the argument that the conditions of USWs in larger urban settings are more negative does not explain the considerably strong school achievement of the USWs in Cuenca. The better school performance of the USWs in Cuenca can also be interpreted as related to the higher educational levels of the USWs parents and to the young age of the sample, and vice versa for USWs in Otavalo and Ambato. However, further research is needed to explain with confidence the differences in school achievement found between the sample sites.

By Gender. The similar school achievement rates of boys and girls showed girls in a more positive position than expected. Comparable to these findings are the ones reported by Cuvi et al. (1989), who found no differences by gender.

The school achievement of boys and girls was similar from the beginning to the end of the study. Moreover, female and male school achievement analyzed by location and age exhibited small differences, in contrast to the findings on school attendance (recall that in school attendance the analyses of these variables by location and age reduced the advantage of the girls).

Intervening factors that might account for the similar school achievement of USW boys and girls and that need further research are: 
(1)The increase in educational opportunities for females during the last two decades (Presidencia, 1992d; Stromquist, 1992; UNICEF/DYA, 1992; Shiefelbein, 1985) which has definitively impacted their educational levels; (2) parental attitudes regarding sons' and daughters' education; (3)a probable higher priority that girls place on education compared to boys, as argued by Ennew (1988).

Further research on school achievement of USWs in other sites, and in other populations is necessary to see whether the similarities found between male and female school achievement are replicated or not. It would also be interesting to follow this sample for a longer span of time to see if changes eventually occur. 


\section{CONCLUDING COMMENTS}

The purpose of this study was to explore the school attendance and achievement of an intervention population of Ecuadorian USWs, looking at variations by location and age, and with a special focus on gender issues. Although the data turned out to be limited, they provided substantial information about the educational behavior of the USWs by gender, location and age.

The findings from this study provide useful information about the distinctive features and behaviors of the sample, by gender, age and location that can be used either for further research, or to address the problem of USWs in the locations studied. The findings by gender allow one to argue that it is not in elementary school attendance or overall achievement that the disadvantaged position of the girls in this sample can be observed. There was, however, some evidence of female disadvantage, for example, the limited high school attendance of the girls 12 and older; the sharp drop in school attendance of the 12-13 year old girls; and, the absence of the $14-15$ year old girls in high school female USWs. Thus, additional research is needed to delve further into these arenas. 
Age proved to be a variable that considerably affected school attendance and achievement of this sample. The findings of the present study showed that the 5 to 11 year old USWs did better at school, both in school attendance and school achievement. These findings confirm the reported higher rates of school attendance for the younger USWs 15 to 11 ) and the lower attendance rates for the 12 to 17 year olds (Garcia and Hernandez, 1992; Presidencia, 1992; Cuvi et al, 1989). They also corroborate the idea that age $12-13$ is some sort of peak or turning point for both school attendance and achievement of the USWs (Presidencia, 1992d).

By location, both school achievement and attendance showed substantial differences, which allows one to speculate about the characteristics of each site or of the USW population in each site. A particular interesting finding was that of school behavior variations in sites that were demographically similar.

Further research is necessary to find out if results similar to these findings are found in other samples. The span of time the USWs were followed gave a fairly clear idea of their school achievement, but a more limited one of school attendance. As mentioned earlier, the stable school attendance distribution of the USWs -- which is not a common feature in this population -- might be partially related to the relatively short follow- 
up period of the present study (18 months which at the most covered 2 school years).

Regarding the worth of education in the lives of this or other samples of USWs, it is not yet possible to make an assessment of whether school has helped them and, if so, in what way. However, it is the opinion of this author based upon other literature, that at least some years of schooling give these children opportunities for leaving the streets. Of course, formal employment may be accompanied by lower earnings and longer work days, but, at the very least, it allows them to avoid the lifelong effect that seems to come from life on the streets (the physical, emotional, intellectual and social development of USWS is seriously impacted) (Myers, 1988, Pennna, 1988). As indicated in the literature, education by itself is not going to solve the problems of this population, unless it is accompanied by a broader set of policies that addresses the causes and conditions of underage street work. Education, though can be a powerful tool, especially if used to raise consciousness and organize a community to address underage street work (Fink and Arnove, 1989; Gomez, 1989; UNICEF, 1989; Freire, 1985). 


\section{REFERENCES}

Acosta-Belen Edna. 1989. "Education." In Latinas of the Americas. A Source Book, ed. Stoner Lynn K. New York: Garland Publishing, Inc.

Afshar, Haleh. 1991. "Women in Development: Myths and Realities;

Some Introductory Notes." In Women, Development, \& Survival in the Third World, ed. Haleh Afshar. New York: Longman.

Amoroso \& Maldonado. 1989. El Papel del Trabajo de la Ninas Vendedoras de Flores (del Barrio La Mariscal) en las Logicas de Subsistencia de sus Unidades Domesticas. Unpublished document. Quito: FLACSO.

Andrade, Javier. 1986. Informe Final de la Investigacion: Minadores de Basura en Quite Guayaquil. Unpublished document. Quito: Instituto Nacional de Formalizacion Obrera y Campos (INFOC).

Andreas, Carol. 1992. When Women Rebel. The Rise of Popular Feminism in Peru. Westport: Lawrence Hill \& Company.

Balarezo, Humberto. 1988. El Nine Trabajador de la Calle en la Ciudad de Cuenca. Unpublished document. Cuenca: INNFA-Accion Social Municipal.

Beneria L. \& Roldan M. 1987. The Crossroads of Class and Gender. The University of Chicago Press.

Bequele, Assefa. 1988. "Emerging Perspectives in the Struggle against Child Labor." In Protecting Working Children, ed. Myers William E. New York: UNICEF.

Berhman, J.R. \& Wolfe B.L. 1979. The Impact of Health and Nutrition on the Number of Surviving Children in a Developing Metropolis. Unpublished document.

Bernal, Maria E. \& Ayala, Ulpiano. 1985. El Trabajo Infantil en Bogota. Seminario Internacional: La Ciudad y los Ninos. Quito- Ecuador. 
Bordia, Anil. 1988. "Education for Working Children in India." In Protecting Working Children, ed. Myers William E. New York: UNICEF.

Boserup, Ester. 1970. "Loss of Status Under European Rule." In Women's Role in Economic Development. St. Martin's Press.

Bourque, S. \& Warren, K. 1987. "Technology, Gender and Development." Daedalus 116 (4).

Braslasvsky, Cecilia. 1992. "Educational Legitimation of Women's Economical Subordination in Argentina." In Women and Education in Latin America. Knowledge, Power and Change, ed. Nelly Stromquist. Lynne Rienner Publishers: USA.

Boyden, Jocelyn. 1988. "Working Children in Lima, Peru." In Protecting Working Children, ed. by Myers William E. New York: UNICEF.

Briones, Guillermo.1987. La Investigacion Evaluativa de Tecnicas de Investigacion Social Aplicadas a la Educacion. Santiago: Programa Interdisciplinario de Investigaciones en Educacion (PIIE).

Bunch \& Carrilo. 1983. "Feminist Perspectives on Women in Development." In Persistent Inequalities, ed. I. Tinker. New York: Oxford University Press.

Carlson \& Richardson. 1990. Christianity, Patriarchy and Abuse. A Feminist Critique. New York: The Pilgrim Press.

Catanzarite Lisa. 1992. "Gender, Education and Employment in Central America: Whose Work Counts?" In Women and Education in Latin America. Knowledge, Power and Change, ed. Nelly Stromquist. Lynne Rienner Publishers: USA.

CEDEJOTAVUNICEF. 1989. Los Ninos Trabajadores de Guayaquil. Guayaquil: UNICEF.

Centro Ecuatoriano de Investigaciones Sociales (CEISE). 1988. "Problems that Concern Women and their Incorporation in Development: The Case of Ecuador." In Women and Economic Development, ed. Kate Young. Berg/UNESCO. 
Charlton, S.E. 1984. "Development and Women." In Women in Third World Development. Westerview Press, 1984.

Childhope. 1988. Diagnostico Situacional de la Nina y Adolescente Trabajadora De y En la Calle. Guatemala. Seminario/Taller 18-19 Oct.1988.

Cochrane Susan. 1983. "Socioeconomic Determinants of Infant and Child Mortality in Developing Countries." In Child Development and International Development: Research-Policy Interfaces, ed. Daniel Wagner. Jossey-Bass Inc. Publishers,

Cuvi M., Naranjo A. \& Herrera A. 1989. Analisis sobre la Situacion de los Menores Trabajadores en la Calle de la Ciudad de Quito, 1ra Fase. Informe Final. Unpublished document.

Deble, Isabelle. 1988. "Reflections on a Methodology fọr Integrating Women's Concerns into Development Strategies." In Women and Economic Development, ed. Kate Young. Berg/UNESCO.

Delgado E. \& Rivadeneira R. 1992. Situacion de la Infancia en el Ecuador. Quito: La Red para la Infancia. Nucleo Ecuador.

DNI, CECAFEC, INNFA, UNICEF. 1993. Legisiacion del Menor. Los Ninos Tenemos Derechos. Quito: DNI, CECAFEC, INNFA, UNICEF.

Dodge, Cole P. 1988. "Among Survivors: Street Kids in Khartoum." In Protecting Working Children. ed. Myers William E. New York: UNICEF.

Ehlers, Tracy B. 1990. "Female Labor and the Family." In Silent Looms. Westerview Press.

Elson, Diane. 1991. "Male Bias in Macro-economics: The Case of Structural Adjustment." In Male Bias in the Development Process, ed. Diane Elson. New York: Westerview Press.

Engle, Patricia L. 1983. "The Effect of Maternal Employment on Children's Welfare in Rural Guatemala." In Child Development and International Development: Research-Policy Interfaces, ed. Daniel Wagner JosseyBass Inc., Publishers

Ennew, J. 1985. Juvenile Street-workers in Lima, Peru. Report for the 
Overseas Development Administration. London: Unpublished document.

Espin, P. 1987. La Comunidad y los Derechos de los Menores en el Ecuador: Estudio de Caso en Varios Tipos de Estructuras Familiares. Quito: Unpublished study.

Fernandez-Kelly, P. 1983. For We're Sold, I and my People. Women and Industry in Mexico's Frontier. Albany: State University of New York Press.

Fink, M. \& Arnove, R. 1989. Current Issues and Tensions in Popular Education in Latin America. Paper presented at the Annual Meeting of the Comparative and International Education Society (Cambridge, MA, March 31-April 2, 1989). Conference paper.

Freire, Paolo. 1973. Education as the Practice of Freedom. New York: Seabury Press.

1985. The Politics of Education: Culture, Power, and Liberation. Massachusetts: Bergin \& Garvey Publishers.

Garcia, M. \& Hernandez, C. 1992. Tiempo de jugar? Ninos y Adolescentes Trabajadores de las Familias Populares Urbanas. Quito: CEPLAES.

Gissi Bustos, Jorge. 1980. "Mythology about Women with Special Reference to Chile." In Sex and Class in Latin America, ed. June Nash, and Helen I. Safa. J.F. Bergin Publishers, Inc.

Gomez Da Costa, Antonio C. 1989. Aventura Pedagogica. Caminos y Descaminos de una Accion Educativa. Serie Divulgativa, no. 3. Programa Regional Menores en Circunstancias Especialmente Dificiles. Bogota: UNICEF.

Grupo Esquel Argentina. 1989. La Problematica de la Minoridad Marginada en Argentina. Programa "De los Pibes". Buenos Aires.

Guerra, G. \& Lorant, V. 1991. El Comportamiento Laboral de los Menores. Quito: UNICEF.

Gunn, S. \& Ostos, Z. 1992. "Dilemmas in Tackling Child Labour: The case of Scavenger Children in the Philippines." International Labour Review, 
vol. 131 , no. 6 .

Hollsteiner, M. \& Tacon, P. 1983. "Migration in Developing Countries:

Consequences for Families and their Children." In Child Development and International Development: Research-Policy Interfaces, ed. Daniel Wagner. Jossey-Bass Inc., Publishers.

lara, H. \& Saffioti Bongiovani. 1980. "Relationship of Sex and Social Class in Brazil." In Sex and Class in Latin America, ed. June Nash, and Helen I. Safa. J.F. Bergin Publishers, Inc.

Instituto Nacional de Estadisticas y Censos (INEC). 1991a. V Censo de Poblacion y IV de Vivienda 1990. Resultados Definitivos: Imbabura. Quito: INEC.

--1991b. V Censo de Poblacion y IV de Vivienda 1990. Resultados Definitivos: Tungurahua. Quito: INEC.

---- 1991c. V Censo de Poblacion y IV de Vivienda 1990. Resultados Definitivos: Azuay. Quito: INEC.

----- 1991d. V Censo de Poblacion y IV de Vivienda 1990. Resumen Nacional. Resultados Definitivos. Quito: INEC.

Instituto Nacional de Empleo (INEM). 1988. Encuesta de Hogares, Quito: INEM.

Instituto Nacional del Nino y la Familia (INNFA). 1992. Informe Sintesis de las Acciones Realizadas por el Instituto del Nino y la Familia. Quito: INNFA.

---- 1989. Manual Operativo para el Promotor del Programa. Quito: INNFA-UNICEF.

---- 1991a. Programa Trabajadores Prematuros. Manual de Funcionamiento. Quito:INNFA.

--- 1991b. Programa Trabajadores Prematuros. Fichas del Sistema de Informacion. Quito:INNFA.

INNFA/UNICEF. 1987. Reunion de Instituciones que Trabajan por el Nino de Calle en Quito y Ambato. Unpublished document. 
International Catholic Child Bureau (ICCB). 1989. "Programme on Street Children and Street Youth. Projects Profile." L' Esperance Commence avec l'Amour. Series No.1. Geneve: ICCB.

--1985. Forum on Street Children and Youth. Grand Bassam, Ivory Coast: ICCB.

Jaquette, Jean. 1990. "Gender and Justice in Economic Development." In Persistent Inequalities, ed. I. Tinker. New York: Oxford University Press.

Landazuri, C. 1992. Evaluacion del Programa Trabajadores Prematuros. Quito: Unpublished Report.

Lenero, Elu de. 1980. "Women's Work and Fertility." In Sex and Class in Latin America, ed. June Nash, and Helen I. Safa. J.F. Bergin Publishers, Inc.

Levine, Robert A. 1983. "Fertility and Child Development: An Anthropological Approach." In Child Development and International Development: Research-Policy Interfaces, ed. by Daniel Wagner Jossey-Bass Inc., Publishers

Lim, Linda. 1983. "Capitalism, Imperialism and Patriarchy: The Dilemma of Third World Women Workers in Multinational Factories." In Women Men and the International Division of Labor, ed. June Nash and Maria Patricia Fernandez-Kelly. Albany: State University Press.

Lindsey, Linda L. 1990."Cross Cultural Perspectives." In Gender Roles: A Sociological Perspective. Englewood Cliffs, N.J: Prentice Hall.

Lobao, Linda. 1993. "Women in Revolution: The Mobilization of latin American Women in Revolutionary Guerrilla Movements." In Feminist Frontiers III, ed. L. Richardson \& V. Taylor.

Lusk, Mark W. 1989. "Street Children Programs in Latin America." Journal of Sociology and Social Welfare. no. 16.

Mancilla, Maria Eugenia. 1988. Los Ninos y Adolescentes en Alto Riesgo y el Trabajo Infantil. Version Preliminar para la Segunda Edicion. Lima.

Marks, Tom. 1992. "Making Revolution with the Shining Path." In The Shining 
Path of Peru, ed. Scott Palmer. New York: St. Martin's Press.

Marquez, R. 1990. Escolares Trabajadores en el Ecuador. Machala: UNICEFDISE.

Moore, Elizabeth. 1983. "Child Labor and National Development: An Annotated Bibliography." In Child Development and International Development: Research-Policy Interfaces, ed. Daniel Wagner. JosseyBass Inc., Publishers.

Moser, C. O. N. 1989. "Gender Planning in the Third World: Meeting Practical and Strategic Gender Needs." World Development, vol. 17, no.11.

MTRH, INNFA, OIT, UNICEF. 1994. Seminario Taller Nacional sobre Trabajo Infantil en el Ecuador. Conclusiones Finales. Quito: Unpublished Document.

Myers, William E. 1988. Protecting Working Children. New York: UNICEF.

Nangia, Parveen. 1988. "The Situation of Working Children in India." In Protecting Working Children, ed. Myers William E. New York: UNICEF.

Nash, June. 1980. "A Critique of Social Science Roles in Latin America." In Sex and Class in Latin America, ed. June Nash, and Helen I. Safa. J.F. Bergin Publishers, Inc.

Nicolo de, Javier, Ardila Irenarco, Castrellon Camilo \& Marino German. 1988. Musaranas. Bogota, Colombia: Servicio Juvenil.

Novillo, N. 1994. Diagnostico de la Situacion Familiar de los Menores del Programa Trabajadores Prematuros. Informe Final. Quito. Unpublished document.

----- 1995. La Politica Estatal frente a la Problematica del Trabajador Prematuro: El Caso de los Menores de y en la Calle. Quito. Enero, 1995. Tesis de Licenciatura en Antropologia. PUCE.

Oloko, Beatrice Adenike. 1988. "Children's Work in Urban Nigeria: A Case Study of Young Lagos Street Traders." In Protecting Working Children. ed. Myers William E. New York: UNICEF. 
Penna, F. Thereza. 1988. "The Generation and Observation of Evaluation Indicators of the Psychosocial Development of Participants in Programs for Street Children." In Protecting Working Children, ed. Myers William E. New York: UNICEF.

Perez, Armando. 1987. La Fuerza del Trabajo en Quito: 1986. Analisis Metodologico y Estructura Ocupacional. Cuaderno Economia No. 2 Instituto de Investigaciones Economicas. Consejo Nacional de Universidades y Escuelas Politecnicas. Quito-Ecuador.

Piloti, D. Francisco J. 1985. El nino en las Ciudades Latinoamericanas: Caracteristicas y Antecedentes para la Formulacion de un Proyecto de Investigacion. Seminario Internacional: La ciudad y los ninos. QuitoEcuador.

Population Reference Bureau. 1986. "Women in the World: The Women's Decade and Beyond." In A Population Learning Series. Washington D.C.

Presidencia de la Republica. 1992a. Plan Nacional de Accion para la Supervivencia. la Proteccion y el Desarrollo del Nino en el Decenio del 90. Menores en Circunstancias Especialmente Dificiles. Quito: Sistema de Naciones Unidas.

1992b. Plan Nacional de Accion para la Supervivencia, la Proteccion y el Desarrollo del Nino en el Decenio del 90. Nutricion. Quito: Sistema de Naciones Unidas.

1992c. Plan Nacional de Accion para la Supervivencia, la Proteccion $y$ el Desarrollo del Nino en el Decenio del 90. Salud. Quito: Sistema de Naciones Unidas.

-.-- 1992d. Plan Nacional de Accion para la

Supervivencia, la Proteccion y el Desarrollo del Nino en el Decenio del 90. Educacion. Quito: Sistema de Naciones Unidas.

1992e. Plan Nacional de Accion para la Supervivencia, la Proteccion y el Desarrollo del Nino en el Decenio del 90. Resumen. Quito: Sistema de Naciones Unidas.

Programa Trabajadores Prematuros (PTP). 1990a. Diagnosis of the

Population of Children who Work in the Streets by City. Quito: Internal 
Document.

- 1990b. Sistema de Informacion y Seguimiento. Quito: Internal Document.

-.-.- 1994a. Sistema de Informacion y Seguimiento del Programa. Quito: Unpublished Document.

-..-- 1994a. Informe Semestral de Actividades. Enero-Junio. Quito: Internal Report.

-.... 1994b. Proyecto de Transferencia del Programa Trabajadores Prematuros del INNFA a Instituciones Publicas y/o Privadas. Quito: Unpublished Document.

Registro Oficial. 1992. Codigo de Menores. Quito: Registro Oficial.

Ritter, Bruce. 1988. Sometimes God has a Kid's Face. USA: Covenant House.

Rodriguez, Rosa. 1993. Rol del Trabajo Infantil en las Unidades Productivas. Quito: Unpublished document.

Ruether, Radford R. 1983. Sexism and God-Talk. Toward a Feminist Theology. Boston: Beacon Press.

Safa, Helen I. 1980. "Class Consciousness." In Sex and Class in Latin America, ed. June Nash and Helen I. Safa. J.F. Bergin Publishers, Inc.

Salazar, Betsy. 1989. Ninez y Trabajo Informal en America Latina: El Caso de Ecuador. Quito: Centro de Promocion y Empleo para el Sector Informal Urbano (CEPESIU). Unpublished document.

Sara-Lafose, Violeta. 1992. "Coeducational Settings and Educational and Social Outcomes in Peru." In Women and Education in Latin America. Knowledge, Power and Change. ed. Nelly Stromquist. Lynne Rienner Publishers: USA.

Serrill, Michael. 1993. Defiling the Children. Time Magazine. Vol. 141, No. 25, February 21: 53-55.

Shiefelbein, Ernesto. 1985. Education Costs and Financing Policies in Latin America. Research Division. Education and Training Department. The 
World Bank. Unpublished Document.

Stromquist, Nelly. 1989. "Recent Developments in Women's Education:

Closer to a Better Social Order?" In The women and International

Development Annual, volume 1, ed. Rita S Gallin, Marilyn Aronnoff and Anne Ferguson. Westerview Press.

1992. "Coeducational Settings and Educational and Social Outcomes in Peru." In Women and Education in Latin America. Knowledge, Power and Change. ed. Nelly Stromquist. Lynne Rienner Publishers: USA.

Tacon, Peter. 1988. "A Global Overview of Social Mobilization on Behalf of Street Children." In Protecting Working Children, ed. Myers William E. New York: UNICEF.

Tapia, Luis. 1984. Los Escolares Trabajadores de Guayaquil y Babahoyo. Guayaquil: INNFA-UNICEF. Unpublished document.

Tarazona Sevillano, Gabriela. 1992. "The Organization of the Shining Path." In The Shining Path of Peru, ed. Scott Palmer. New York: St. Martin's Press.

Tenorio Rodrigo. 1992. La Familia. Quito: Direccion Nacional de la Mujer Ministerio de Bienestar Social.

Tinker Irene. 1990. "A Context for the Field and for the Book." In Persistent Inequalities, by I. Tinker. New York: Oxford University Press.

UNICEF \& OIT. 1994. El Trabajo de los Ninos y de los Adolescentes en el Ecuador. Problemas y Alternativas. Quito: Unpublished Study.

UNICEF \& DYA. 1992. Bienestar de los Ninos en el Ecuador. Informe 1992. Quito: UNICEF

UNICEF. 1989. Paulo Freire y los Educadores de la Calle. Serie Metodologica No. 1. Bogota: Editorial Gente Nueva.

1990. Ecuador. Menores en Circunstancias Especialmente Dificiles. Analisis de Situacion. Quito-Ecuador: Unpublished document.

United Nations Social Defence Research Institute (UNSDRI). 1986. Action- 
Oriented research on Youth Crime. An International Perspective.

Publication no. 27, ed. Ugljesa Zcevic.

Wagner, D. 1983. "Indigenous Education and Literacy in the Third World." In Child Development and International Development: Research-Policy Interfaces, ed. Daniel Wagner Jossey-Bass Inc., Publishers.

Wright, J., Wittig, M., Kaminsky D. 1993. "Street Children in North and Latin America: Preliminary Data from Proyecto Alternativos in Tegucicalpa and Some comparisons with the U.S. Case." Studies in Comparative International Development, vol 28, no.2, 81-92.

-1993. "Health and Social Conditions of Street Children in Honduras." The American Journal of diseases of children, vol. 147, March, 279283.

Yopo, Boris. 1989. Sistematizacion del Segundo Encuentro de Investigadores de America Latina sobre Ninas de y en la Calle. Guatemala: Childhope.

Young, Kate. 1988. "Reflection on Meeting Women's Needs." In Women and Economic Development, ed. Kate Young. Berg/UNESCO 
Appendix A

VARIABLE CODE BOOK

NAME

location

gender

age (base line)

age 2 (end follow up)

School attendance 1 (base line)

S1

S2

S3

S4

School attendance 2 (evaluation No.1)

School attendance 3 (evaluation No.2)

$\begin{array}{ll}\text { CODE } & \text { VALUE } \\ \text { city } & \begin{array}{l}1=\text { Otavalo } \\ 2=\text { Ambato } \\ 3=\text { Cuenca }\end{array} \\ & \\ \text { sex } & 1=\text { male } \\ & 2=\text { female } \\ \text { age1 } & 5 \text { to } 17 \\ & \text { recoded by groups: } \\ & 0=5 \text { to } 11 \\ & 1=12 \text { to } 17 \\ & \\ & 6.5 \text { to } 18.5 \\ \text { age2 } & \text { recoded by groups: } \\ & 0=6.5 \text { to } 12.5 \\ & 1=13.5 \text { to } 18.5\end{array}$

School attendance 4 (evaluation No.3)
1

$1=$ yes $/ 2=$ no

$1=$ yes $/ 2=$ no

$$
1=\text { yes } / 2=\text { no }
$$

$1=$ yes $/ 2=$ no 
School Achievement 1

(base line)

A1

$0=$ finished

School Achievement 2

(evaluation No. 1)

A2

$1=$ excellent

2 = very good

School Achievement 3

(evaluation No. 2)

$3=$ good

$4=$ average

$5=$ deficient

$6=$ non-applicable

School Achievement 4 (evaluation No. 3) 